\title{
Evolution of Floor Construction System in Beirut (1840-1940)
}

\author{
Jad Hammoud $^{1} \&$ Elise Abi Rached ${ }^{2}$ \\ ${ }^{1}$ Faculty of Fine arts and Architecture, Lebanese University. Hadath Campus, Branch I, Beirut, Lebanon \\ ${ }^{2}$ Faculty of Fine arts and Architecture, Lebanese University. Furn El Chebbek, Branch II, Beirut, Lebanon \\ Correspondence: Jad Hammoud, Faculty of Fine arts and Architecture, Lebanese University. Hadath Campus, \\ Branch I, Beirut, Lebanon. E-mail: jadwhammoud@gmail.com, eliseabirached@hotmail.com
}

Received: April 24, 2020; Accepted: May 13, 2020; Published: May 21, 2020

\begin{abstract}
This article is going to deal with the evolution of floor structural systems; traditional structural systems during the late Ottoman period and the concrete structural systems during the French mandate period in Beirut. Beyond this, natural constraint timber materials used in the late nineteenth century and the available concrete materials used in the early twentieth century can direct influence the evolution of the floor structural systems which became an integral part of architectural design and typology. Structural principles of traditional floor construction techniques will be characterized and assessed in eight case studies tracing its structural systems in terms of their evolution. The subject matter will be approached in a descriptive manner for floor structural systems and the determination of mechanical properties of timber.
\end{abstract}

Keywords: timber flooring system, floor construction systems, timber materials

\section{Introduction}

There is a Korean saying, "Even if the beads are too much, they become treasure after sewn". This implies importance of technologies and construction. During late nineteenth century, innovations in methods and materials have given new expression to architecture and the human footprint in Beirut. Construction and building materials showed to be so important in the evolution of architectural typologies. Although there are not almost any detailed research studies on the construction techniques of the buildings dated to the late nineteenth and early twentieth centuries, but understanding an overview of the previous researches that were done on the traditional domestic architecture in old Beirut can draw the development of characteristics that led to the acknowledgement of Beirut built heritage. Prior to 1860 , the floors of the traditional nineteenth century houses in Beirut were built using a limited palette of standard materials of local origin: Mud, sand, twigs, brushwood and timber beams. As time passes, period of Ottoman reformation began to modernize Beirut city. floor structural forms have occurred and developed in various types by using available and proper natural timber materials. In 1840s, Beirut was integrated into the capitalist market through commercial exchange through which Beirut exported the Lebanese silk, olive oil and other products to France, Italy and Antolia, in return to a new industrial standardized building materials like roof floor tiles, marble slabs, iron and wood beams in massive quantities imposing standard rules of proportions to the new floor construction system with greater height and span forming the Beiruti bourgeoisie House. In 1920, early French mandate period, a dramatic change in the building industry occurred when cement was gradually incorporated in domestic construction. Concrete started to be emerged, and a progressive densification comes as a result of changes in construction regulations giving place to the appearance of a new horizontal floor structures. The way of understanding the development of the floor structural systems is to characterize and analyse the floor structural technology for eight case studies, six case studies dated to the late Ottoman Period and two for the French Mandate period, which represents all specific characteristics of the Bourgeoisie architecture in Beirut. In this sense, the paper will characterize the construction of floor slabs belonging to the transition period of Ottoman to French mandate to fulfil the gap about the changes in Building construction during this transition period and to establish the new possibilities available for all the agents involved in the future conservation of the architectural heritage.

\section{Methodology}

The scope of this paper is to give an overview of late Ottoman and early French Mandate periods developments by using the quantitative method carried out in the field to understand and deepen the knowledge on floor construction systems which helps the historic building achieve conservation aims while improving the quality of 
its future interventions. This will show how to identify the cultural and historic significance of the architectural heritage in its tangible forms which include historic building between 1840\&1940, to retain the meaning for the society in which it exists. Furthermore, this paper will cover the major topic of the developments of the whole construction system. The intention is to give the key aspect of providing a link from the past to the present, and convey it into the future by highlighting the importance of studying traditional technologies and taking lessons from them in systematic and methodical research. Thus, discussing how history contributed to the development and formation of flooring system in Beirut is very important. Concentrating on construction processes, innovation in construction techniques and the interaction of construction, form and features of the building, had direct influence on the architectural typology as consequence of the architectural demands related to the change of economy and trading system.

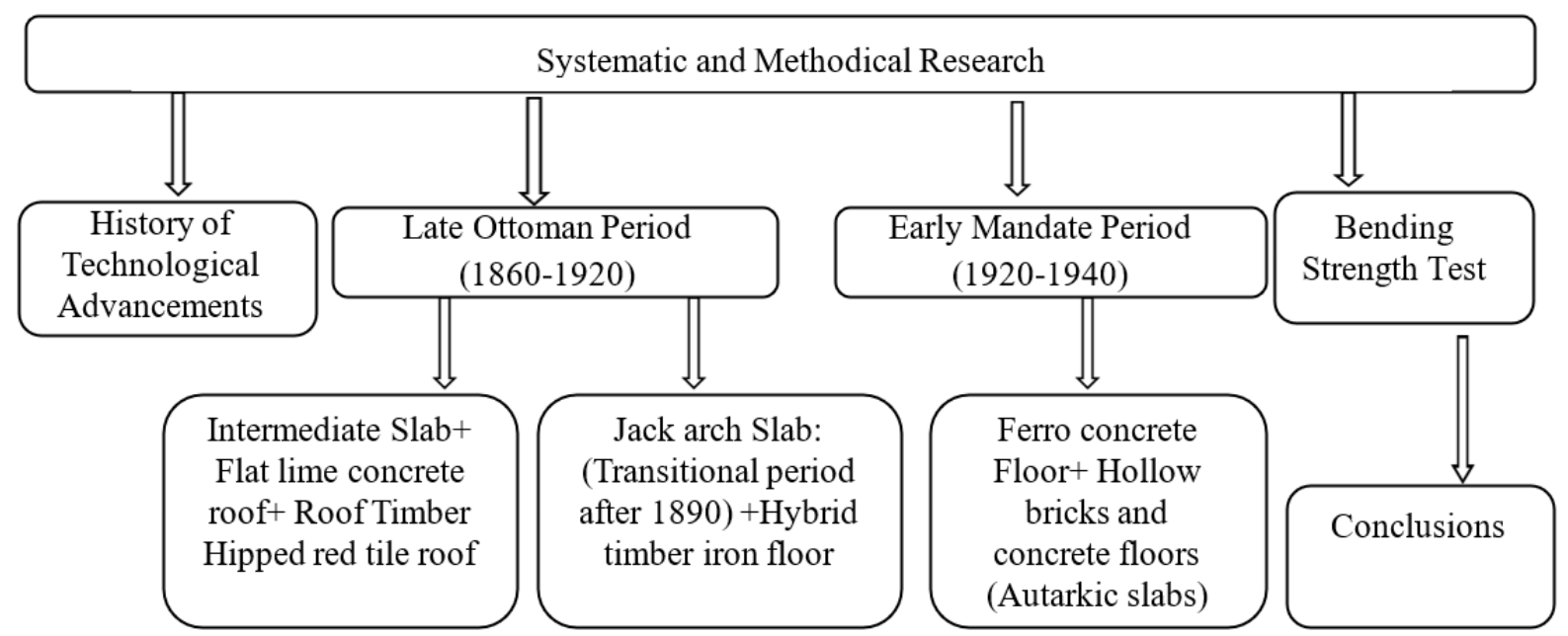

\section{Background History of the Technological Advancements}

There is no need to trace the pattern through all the centuries, but I must go back in history of Beirut to the beginning of the nineteenth century because of a process which is important to notice the first sign of construction had appeared. Until 1835, Beirut was a fortified seaport town surrounded by gardens. Based on many researches, and discoveries that were done on the traditional domestic architecture in old Beirut (Madame de Perthuis.1853), stone houses were built along the street line and a dense network of lanes and blind alley. Local wood had been used as a construction material and had always been a prominent material in the construction of slabs for many reasons. It was one of the traditional building materials with known characteristics that was easy worked, has durability, local availability, lightness, and aesthetics. Due to its material characteristics and natural form, it was convenient to be used in the construction of floors with limited spans. Several habitation types starting from the peasant or farmer house to the Iwan house were found. The predominant type was the Iwan house that consisted mostly of three adjacent rooms where the middle room is called the iwan, that has a large arch perpendicular to the street and oriented to the north (Figure 1\&2). The floors of these houses were characterized by its flat surface supported along its edge. Since spanning means bending, then the use of compressible material was impossible. The only solution was timber beams carrying a heavy earth slab. Prior 1840s, good timber for large spans was rare. So, the room width depending on the beams available was limited to 3.5 meters. Many thin primary beams close to each other or few large beams at some distance were bridged by another layer of smaller secondary joists at right angle (Figure 3). A third layer parallel to the primary beams in the form of reed matting, brushwood, upon which finally the earth slab is placed (Ragette, F. 1998). 


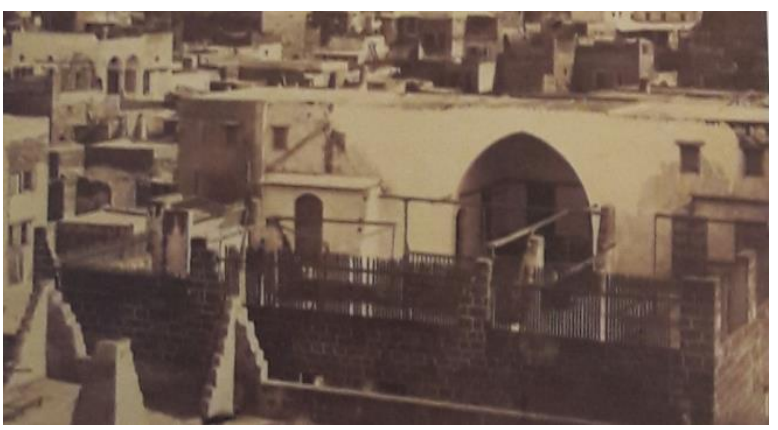

Figure 1. Iwan House (Maison Bonfils, aerial panorama of Beirut, World Digital Library)

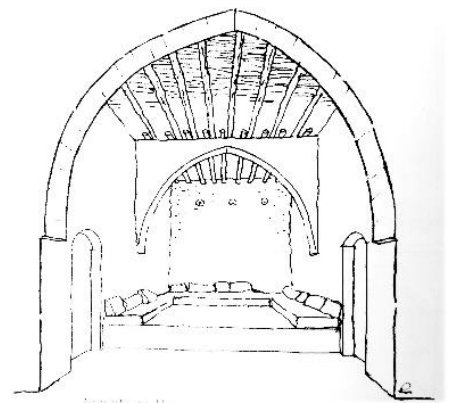

Figure 2. Iwan with wood beams on transverse arches (Ragette, F. 1998)

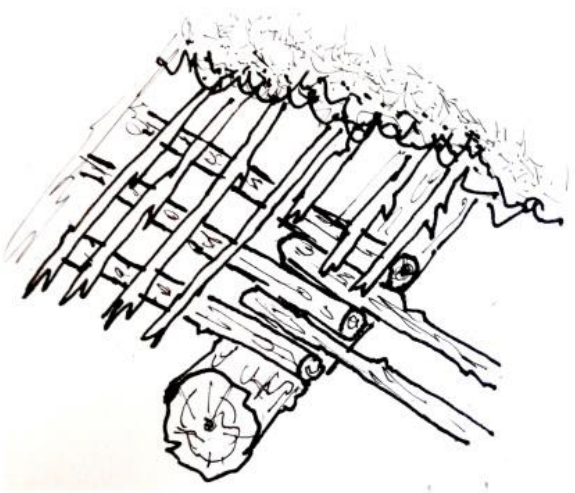

Figure 3. Timber girder with staggered wood beams, layer of twigs and brushwood to receive mud slab (Retrieved from Ragette, F. 1998).

During the second part of the $19^{\text {th }}$ century, the wealthy merchant class designed new prestigious mansions, the Beiruti house with its triple arch, due to the foreign building materials combined and imported from different sources: wrought-iron I-beams and roof tiles from France, mechanically-cut timber from Romania, cast-iron balustrades and hardware from England, and marble tiles and slabs from Italy (Sehnaoui, N. 1981). According to Ragette, these houses consist of a central hall surrounded by rooms on two or three sides (Ragette, F. 1998). The central hall opens through a triple arched opening in the middle of the façade situated usually to the north. The central hall layout requires a tripartite division in the overall arrangement of the plan. The spatial arrangement of this layout requires 12 to 15 meters width according to case studies surveys, which means that the average width of the central hall is approximately 5 meters (Figure 4).
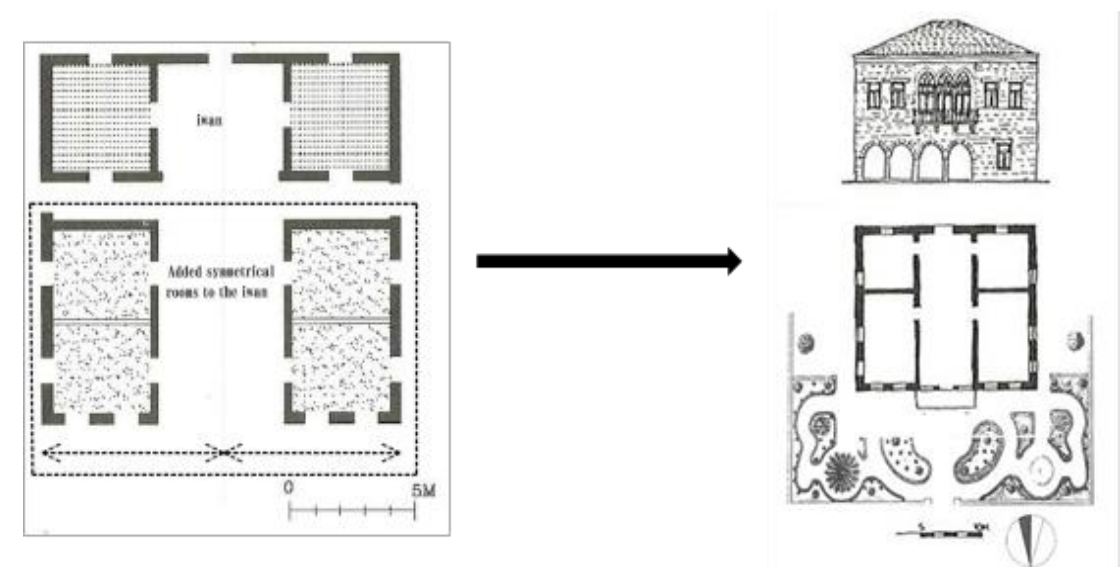

Figure 4. (a)The two symmetrical rooms were added to form a covered hall. (After Fischfisch, 2011), (b) Type of Beiruti house consisting of tripartite plan and roof frame of timber with red tile. The central hall and its main façade oriented to the north and the garden (after Ragette, 2006) 


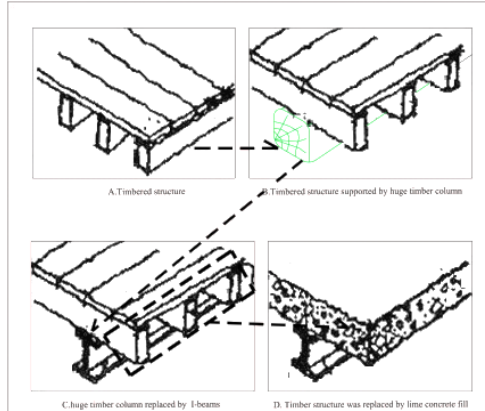

Figure 5. Evolution of floor construction from traditional to transitional structures (Saliba, R. (1998).

This process should be qualified as empirical since it was informed by a traditional knowledge while still open to new materials. During this phase, the ground floor was usually vaulted, while the intermediate floors consisted of a timber frame with machine-cut beams. Their spacing and dimensioning were based on empirical experience. During 1890s, I-beams were added to reinforce the timber floors. At a later stage, hybrid structures were simplified, keeping the I-beams with lime concrete fill (Figure 5). Finally, the pitched roofs were replaced by the concrete slab announcing the second generation of post-industrial buildings and the start of the scientific phase (Saliba, R. 1998). In brief, this empirical phase may be qualified as 1) a passage from a traditional to a semi-industrial order through the merging of local and imported materials by the builders themselves, and 2) as a sharp break with the past with the imposition of new materials, techniques and programs designed by European architects and engineers in isolation from the local building culture. During this phase, the duality between builders and engineers was not apparent (Saliba, R. 1998).

\section{Brief Description of the Case Studies}

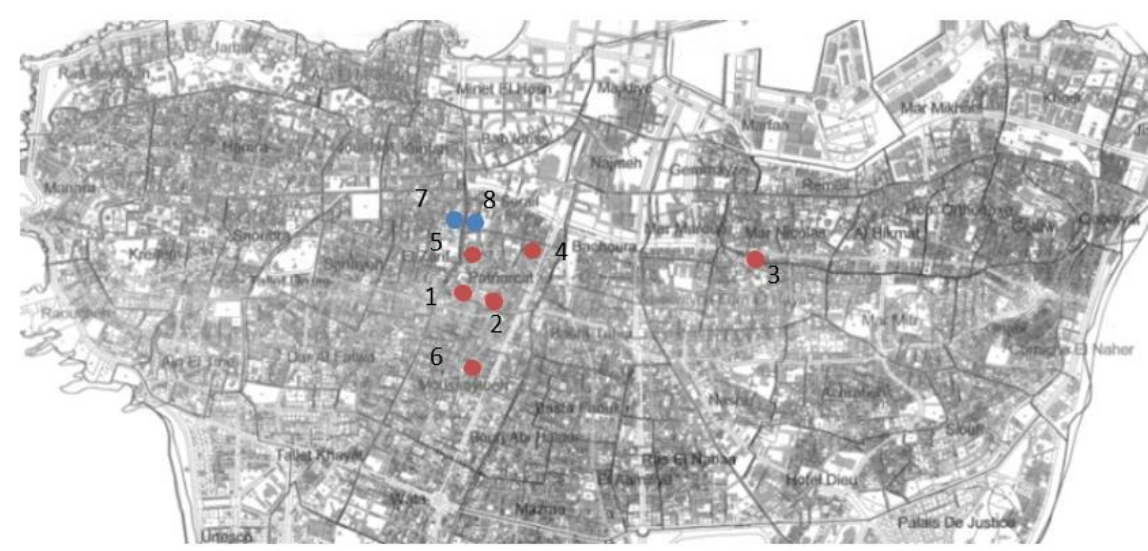

1- Bchara El Khoury Mansion

2- Kaaki House

3- Achrafiyye House

4- Al Sabra House

5- Fairuz House

6- Taweel House

7- Farjallah Building

8- Kabbani Building

Figure 6. Location of the surveyed buildings in Beirut

The reason for the selection of the residential buildings in Beirut is that there are not almost any detailed research studies on the construction techniques of these buildings, dating to the late Ottoman Period and the French Mandate period, which represents all specific characteristics of the Bourgeoisie architecture in Beirut (Table 1). In the light of the aim mentioned, the paper is focusing on traditional Bourgeoisie residential buildings. Among the case studies, four of them are registered and classified. The selection of buildings in Beirut is mostly for reasons:

- Selected buildings are classic examples of Beiruti Bourgeoisie residential buildings with their scale, Floor and roof construction techniques, and use of material.

- All the selected buildings were designed originally as a residential building.

- All the selected buildings are not undergone through restorations. Therefore they still preserve their original construction details. 
Table 1. Brief Description of Case Studies (Hammoud J., 2020)

\begin{tabular}{|c|c|c|c|c|c|c|c|}
\hline \# & Building & $\begin{array}{l}\text { Span } \\
\text { limitation } \\
(\mathrm{cm}) \\
\end{array}$ & $\begin{array}{l}\text { No. of } \\
\text { stories }\end{array}$ & $\begin{array}{l}\text { Floor } \\
\text { Area }\end{array}$ & $\begin{array}{l}\text { Floor } \\
\text { Roof }\end{array}$ & Use & Date of construction \\
\hline B1 & $\begin{array}{l}\text { Bchara el- } \\
\text { Khoury }\end{array}$ & 610 & 2 & 450 & \multirow{2}{*}{$\begin{array}{l}\text {.Jack Arch } \\
\text {.King Post } \\
\text {.Intermediate } \\
\text {.Queen Post }\end{array}$} & Residential & Late $19^{\text {th }}$ Century \\
\hline B2 & Kaaki & 530 & 2 & 280 & & Residential & Late $19^{\text {th }}$ Century \\
\hline B3 & Ashrafiyyeh & 385 & 3 & 180 & $\begin{array}{l}\text {.Intermediate } \\
\text {.Queen Post }\end{array}$ & Residential & Late $19^{\text {th }}$ Century \\
\hline B4 & Al-Sabra & 570 & 2 & 275 & $\begin{array}{l}\text { Hybrid } \\
\text { King Post } \\
\text {.Intermediate }\end{array}$ & Residential & Late $19^{\text {th }}$ Century \\
\hline B5 & Fairuz & 570 & 3 & 210 & $\begin{array}{l}\text { \& Jack Arch } \\
\text {. King Post }\end{array}$ & Residential & Early $19^{\text {th }}$ Century \\
\hline B6 & Taweel & 550 & 2 & 275 & $\begin{array}{l}\text {.Intermediate } \\
\text { King Post }\end{array}$ & Residential & Late $19^{\text {th }}$ Century \\
\hline B7 & Farjallah & 415 & 4 & 170 & $\begin{array}{l}\text {.Autarkic } \\
\text { slabs) .Ferroco } \\
\text { ncrete }\end{array}$ & Residential & Late French Mandate \\
\hline B8 & Kabbani & 360 & 5 & 140 & Ferroconcrete & Residential & Early French Mandate \\
\hline
\end{tabular}

\subsection{Case study 1 (Bchara el-Khoury Mansion)}

The mansion consists of a basement and two storeys above. Seen from outside, Bchara el-Khoury mansion is a quite imposing loadbearing structure. The ceiling is almost 5.7 meters high carried by long iron girder with I-shape and vaulted stones run in between, supported at the stone walls in most rooms and short wooden beams and fillings in secondary rooms; all lime plastered and painted stucco in cream color. The spaces above the girders are screened with substrates. Iron girders with I shape section are used to span the outer space of the arched gallery that is used as balcony (Figure $7 \& 8$ ). The last floor is in bad condition due to water infiltration from its damaged hipped roof.

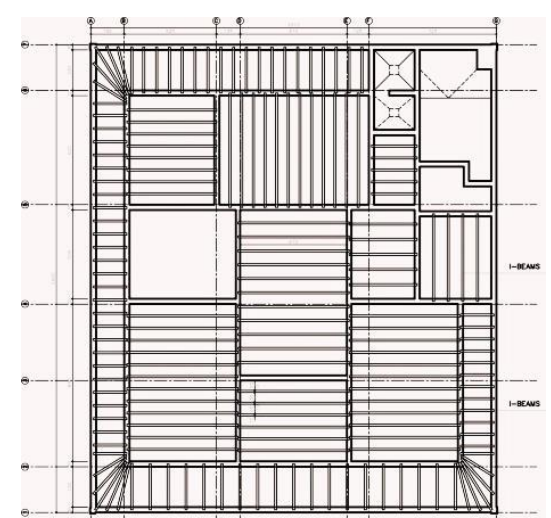

Figure 7. The Jack arch slab used in the first floor plan. (Hammoud J., 2019).

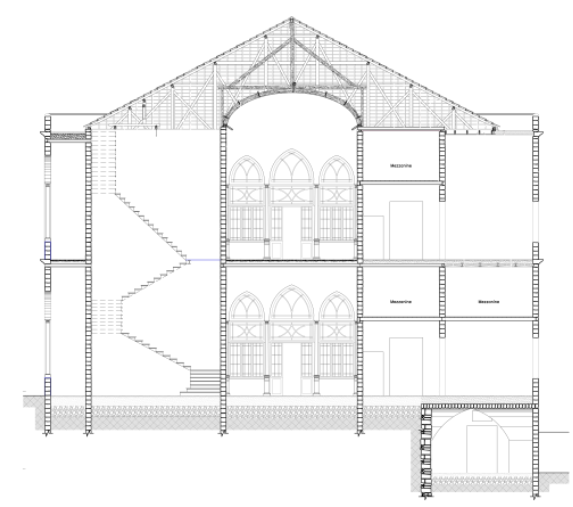

Figure 8. Section in Bchara el-khoury mansion. (Abi Rached,E. 2019).

\subsection{Case study 2 (Kaaki House)}

The house is built in plastered sandstone masonry and is consisting of two floors, a ground, first and a red tiled hip-roof (Figure 9 \&10). The façade is covered by red-tiled hipped roof while the part having the kitchen and toilets called Annex are flat roof (Figure 11). The intermediate floor has main wooden girders. Above it runs the cross beams carrying wooden fillings. The ceilings are carried by long wooden beams at the stone walls. The spaces above the beams are screened with substrates. 


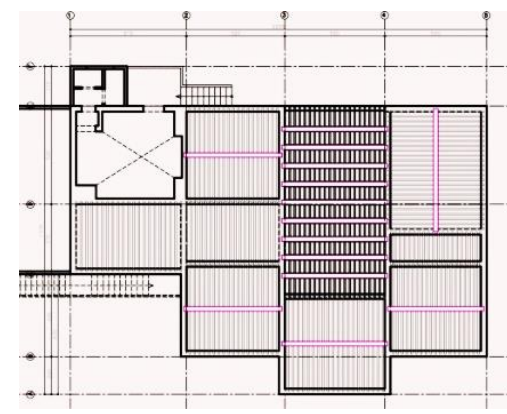

Figure 9. Intermediate slab used in Kaaki house and the vaulted kitchen at ground floor plan.

(Hammoud J., 2019).

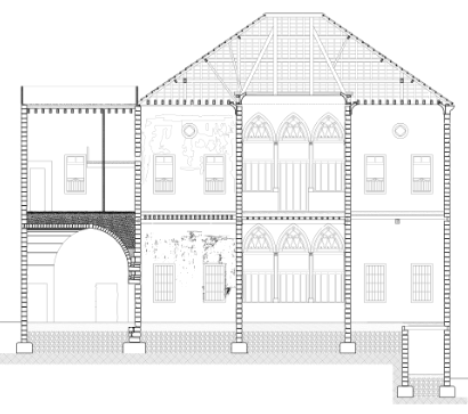

Figure 10. Section showing the intermediate slab and the Queen post roof. (Hammoud J., 2019).

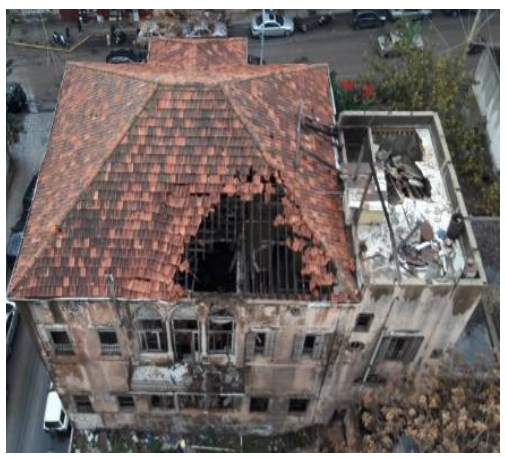

Figure 11. Top view of Kaaki house (Hammoud J., 2017).

\subsection{Case Study 3 (Ashrafiyyeh House)}

The house is one of small surviving houses which were built during the 1870s. The house is a quite loadbearing structure built in plastered sandstone masonry and is consisting of three floors, a ground, first, second and a red tiled hip-roof (Figure 12, $13 \&$ 14). The ground floor is vaulted. The first floor ceiling has main iron girders. Above it runs the cross beams carrying wooden fillings. The ceilings are carried by long wooden beams at the stone walls. The spaces above the beams are screened with substrates.

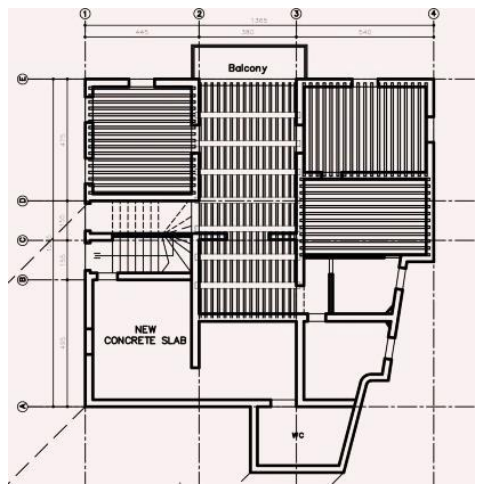

Figure 12. The Intermediate slab first floor plan (Hammoud J., 2019).

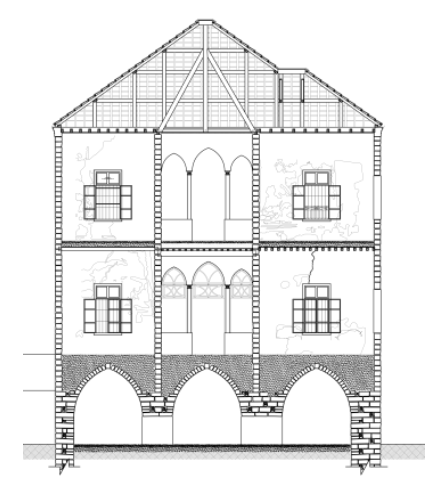

Figure 13. Section showing the intermediate slab and the king post roof construction.

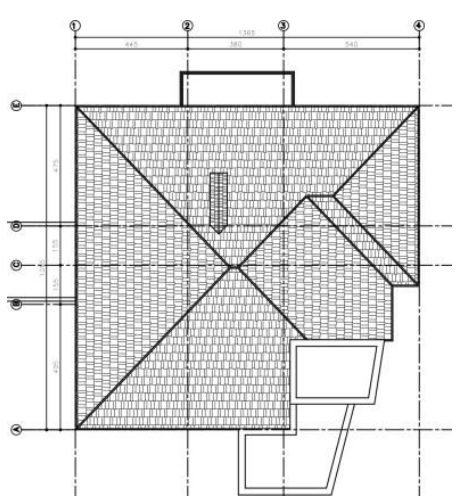

Figure 14. Mass plan (Hammoud J., 2017).

\subsection{Case Study 3 (Al Sabra House)}

The house is a quite loadbearing structure built in 1890s. This house is distinguished from the other houses dated to same period by its red-tiled steeple valley hip roof (Figure $16 \& 17$ ). Its main façade has a wall surface extending into gable without break. The intermediate floor has same details as other houses except in the central hall that has I-Beams girder carried on the sandstone walls. Wooden joists connect the I-Beams forming a composite slab (Figure 15). 


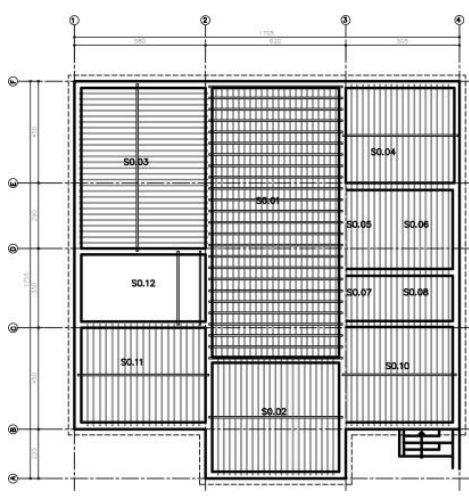

Figure 15. The first floor structural plan. (Hammoud J., 2019).

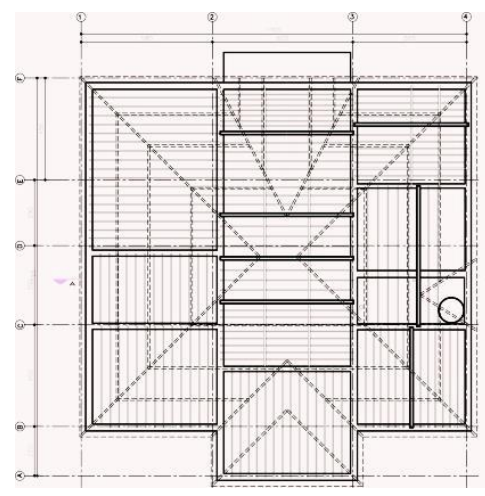

Figure 16. The king post roof construction plan (Hammoud J., 2019).

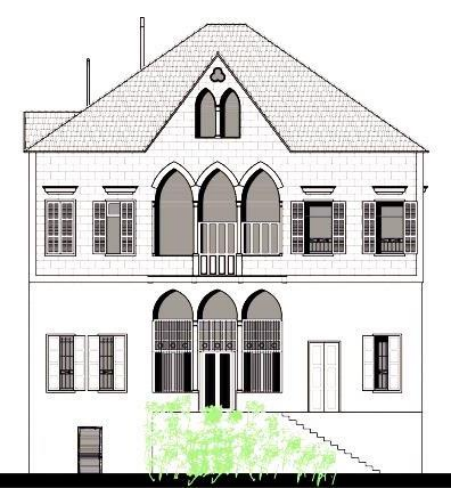

Figure 17. North Elevation showing the valley hipped roof

(Abi Rached,E. 2019).

\subsection{Case Study 5 (Fairuz house)}

The house dates back to the beginning of the nineteenth century at the time of the Ottoman Empire. The house is a loadbearing structure, built in plastered sandstone masonry and is consisting of three floors, a ground floor (Figure 18), first floor which is covered with red tiled hip-roof, and the second floor covered with small red tiled hip-roof making the façade in two levels which is different from other surviving houses in Beirut. The ceiling in the ground floor consists of cross beams carrying wooden fillings in the rooms and has main iron girders with vaulted stones in between in the kitchen (Figure 19 \& 20).

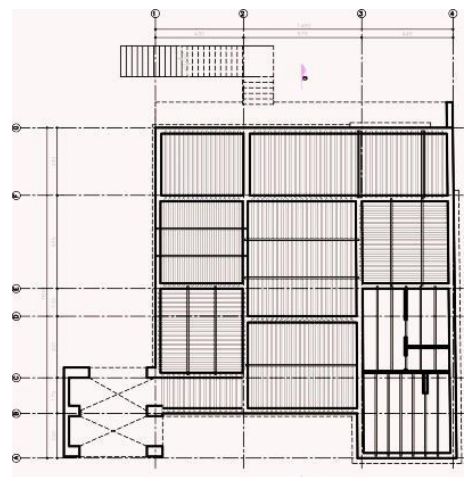

Figure 18. The intermediate slab construction in all rooms except the jack arch in the kitchen.

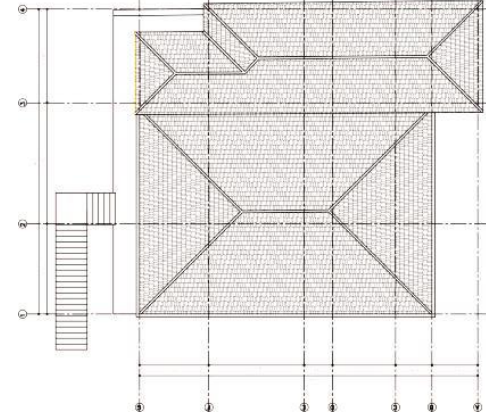

Figure 19. The hipped roof in two levels (Abi Rached, E. 2019).

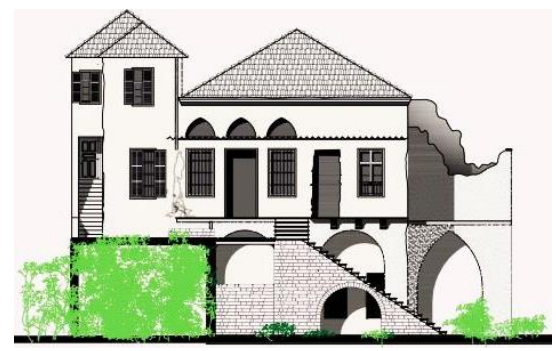

Figure 20. Fairuz house (Abi Rached,E. 2019).

\subsection{Case Study 6 (Taweel house)}

The house was constructed in the late Ottoman period (late nineteenth century), it consists of two stories and a red tiled hip-roof. The house is a loadbearing structure built in plastered sandstone masonry. The façade is covered by red-tiled hipped roof while the part having the kitchen and toilets are flat roof. The intermediate floor has as main wooden girders. Above it runs the cross beams carrying wooden fillings to receive the substrates on it. The kitchen on the ground floor is vaulted (Figure 21). The first floor ceiling is covered by hipped roof except the kitchen that is covered with lime concrete ceiling (Figure 22). 


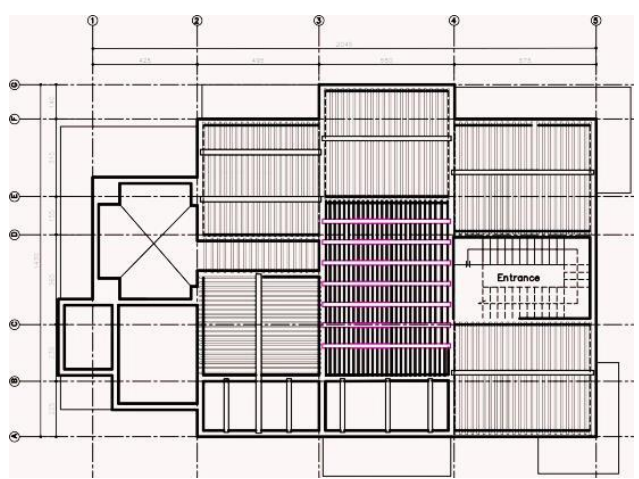

Figure 21. The ground floor structural plan. (Abi Rached, E. 2019).

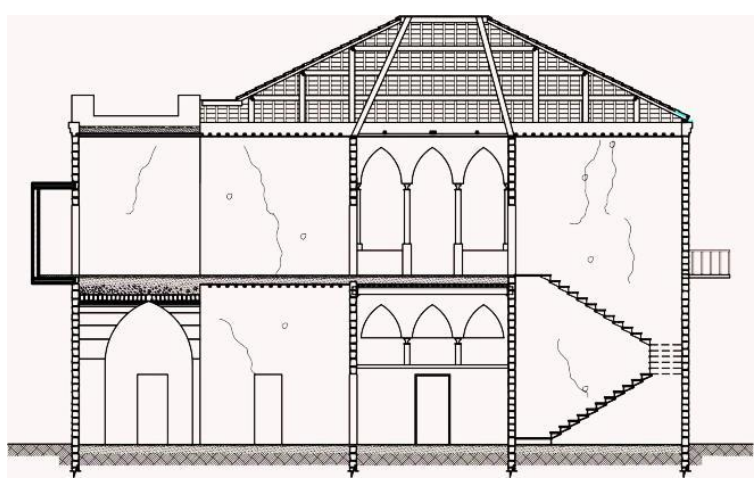

Figure 22. The king post roof construction and the Annex to the left (Hammoud J., 2019).

\subsection{Case Study 7 (Farjallah building)}

This building is a four-floor building consists of eastern and western halves and was built at the beginning of the twentieth century (late French mandate period). The building is a non-loadbearing structure. The reinforced concrete floors are carried by reinforced concrete columns. The important thing observed in each floor is a concrete floor slabs supported on drop beams spanning onto columns and stone walls. The fourth floor has different structure; the slab contains common pieces of one-way hollow brick and concrete joist systems (Figure 23 \& 24).

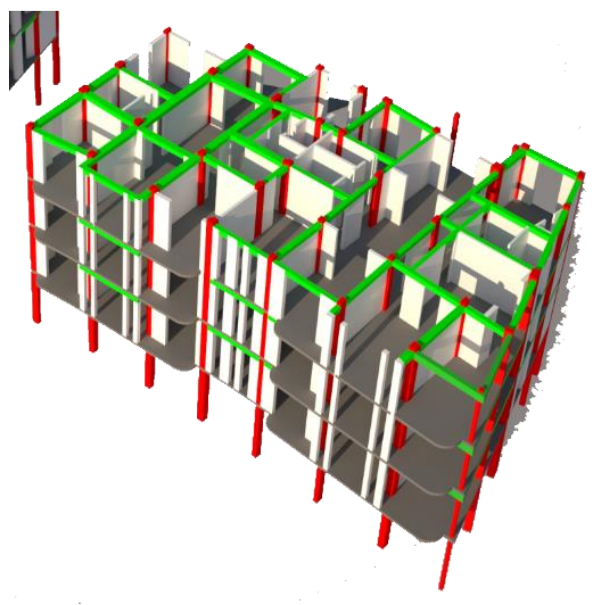

Figure 23. Concrete hybrid system (Columns, beams and Slabs) (Hammoud J., 2019)

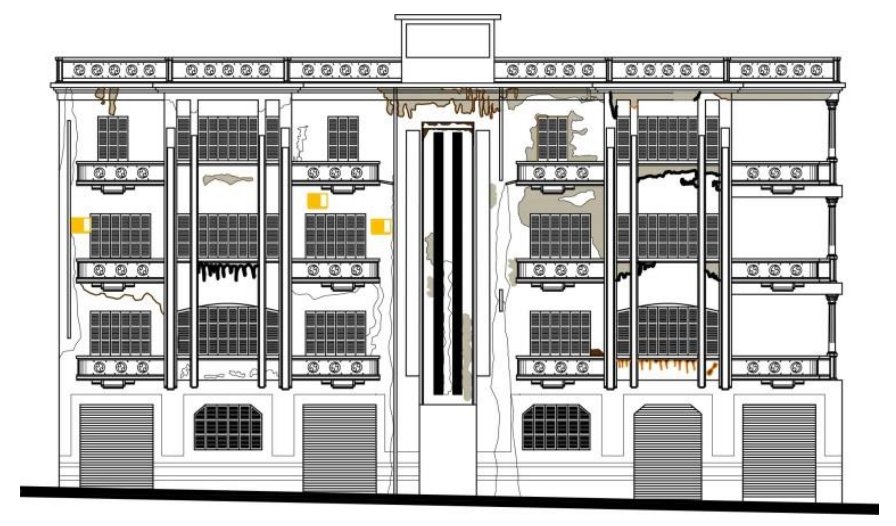

Figure 24. Main street elevation(Hammoud J., 2018)

\subsection{Case Study 7 (Kabbani building)}

This building is a typical five-floor building was built at the beginning of the twentieth century (early French mandate period). The building is a non-loadbearing structure. Hybrid methods are used in construction. The reinforced concrete floors are carried by reinforced concrete columns where local sand stones form the walls of 25 $\mathrm{cm}$ thickness in between. The important thing observed in each floor is a large number of concrete floor slabs supported on down standing beams spanning onto columns and stone walls (Figure 25 \& 26). 


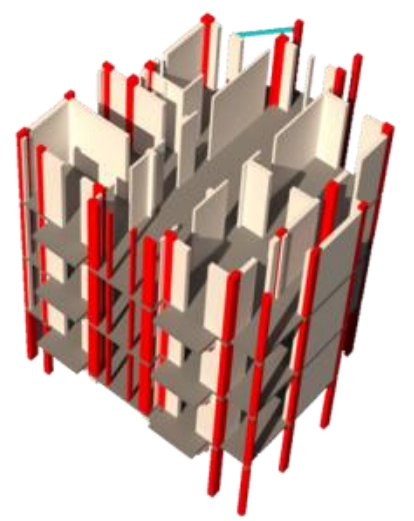

Figure 25. Concrete hybrid system (Columns, beams and Slabs) (Hammoud J., 2019)

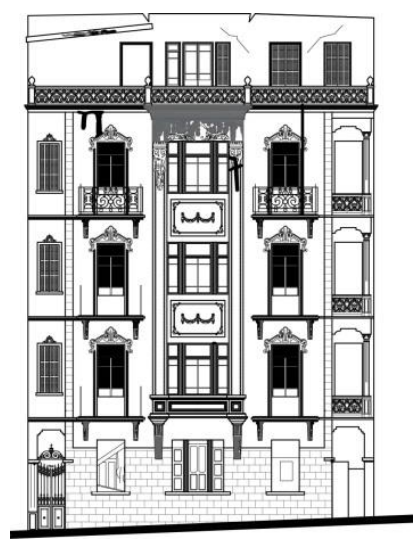

Figure 26. Main street elevation (Hammoud J., 2018)

\section{Traditional Technological Innovations of Floor Structural Systems (1840-1940)}

\subsection{Construction System - Floor Structural Systems (Late Ottoman Period)}

The Flooring structural system consists of both the structural floor slab and any beams supporting it. Flooring system forms a horizontal diaphragm at each level where they occur and transfer loads to walls below. Several questionnaires were asked for the kind of the intermediate floor built in Beirut. It was found five types of Floor techniques constructed between one generation and another.

Type 1: Arched vaulted (ending in the second half of the nineteenth century).The ground floor of some central hall houses in Beirut was arched vaulted (Figure 27). The vaulting cannot be built of uncut stones. The kind of vaulting is like the half spherical dome requires rotational symmetry depending on whether it is a real or blind arcade. As shown in figure 28 , scaffolding is erected inside the building, but the vaulting can only be built from the top of the supporting wall. At the same time the half wall provides a helpful position for the masonry work for the vaulting. As the first step, the half walls are built up to the possible height. Following this, we mold and build the lower part of the rotational symmetric vaulting. The wall filling is required for the continuation of the building process, because it serves as the support for the half way scaffolding. From the wall filling we finish the knee wall, and from this we finish the vaulting.

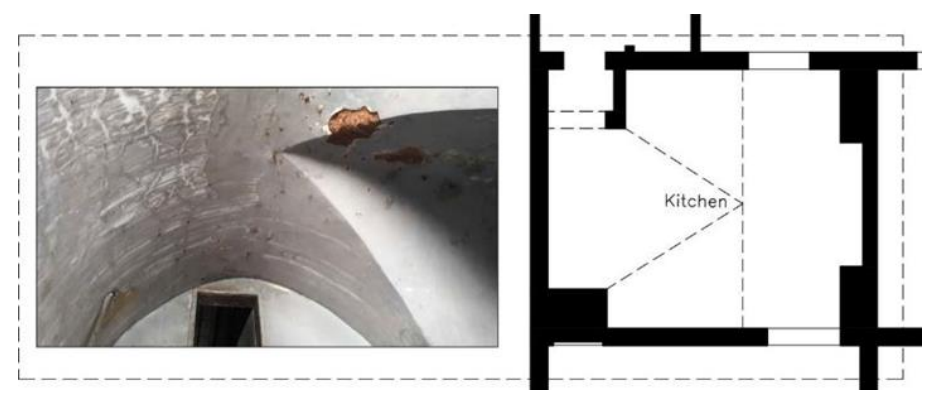

Figure 27. The arched vaulted floor in Kaaki house(Hammoud J., 2017)
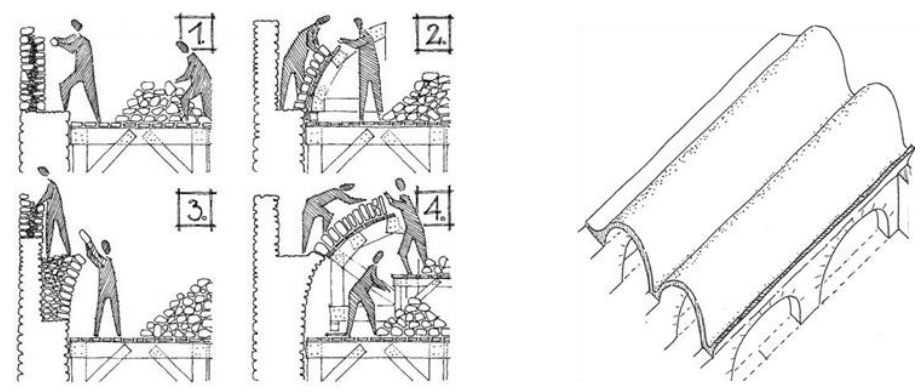

Figure 28. Construction process of the vaulted arch (Bothara et al. 2002) 
Type 2: Intermediate slabs: (1840-1900s): Floors are constructed laying girders at short spans of the walls. Timber floors are constructed by placing the floor wooden girders that have a cross section about $17 \times 9 \mathrm{~cm}$. The floor girders are put in a row that consists of single layers. The wooden girders are carried on large spanned machinecut beams having a cross section of around $25 \times 25 \mathrm{~cm}$ linked to the walls. Afterwards the wooden girders and the machine cut beams are inserted around $15 \mathrm{~cm}$ into the walls. The top of the floor girders was covered with the timber flooring boards $(20 \times 2 \mathrm{~cm})$ perpendicular to them (Figure 29-32).

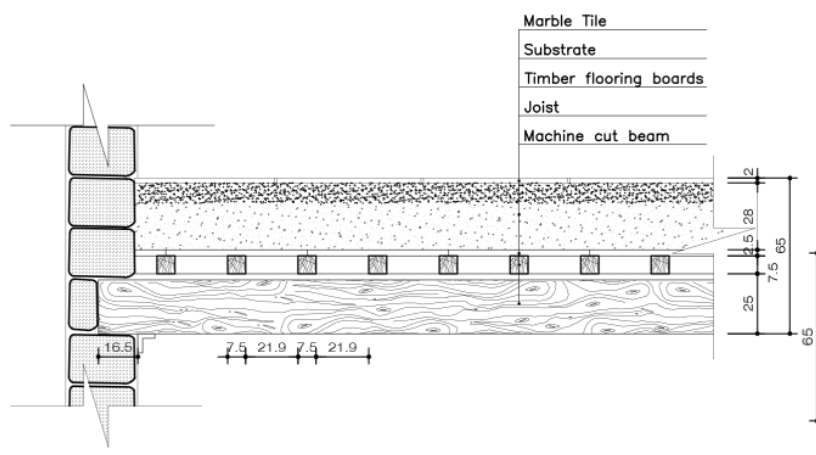

Figure 29. Transversal section for the intermediate slab surveyed in the case study, central hall of Kaaki house (Abi Rached,E. 2019).

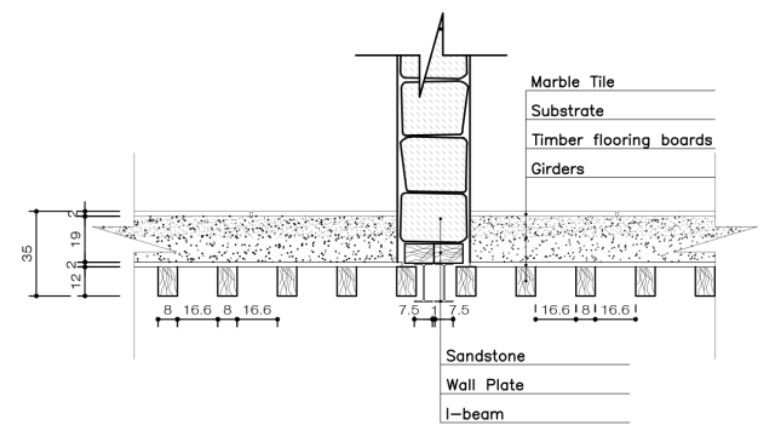

Figure 31. An intermediate slab in Fairuz house showing how sandstone wall was implemented on Ibeams (Abi Rached,E. 2019).

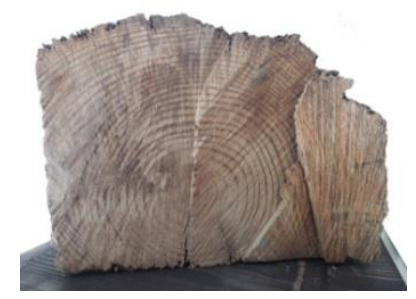

Figure 33. Section of the main beams and (Hammoud J., 2019)

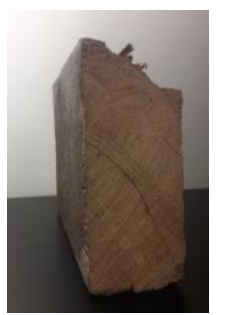
2019).

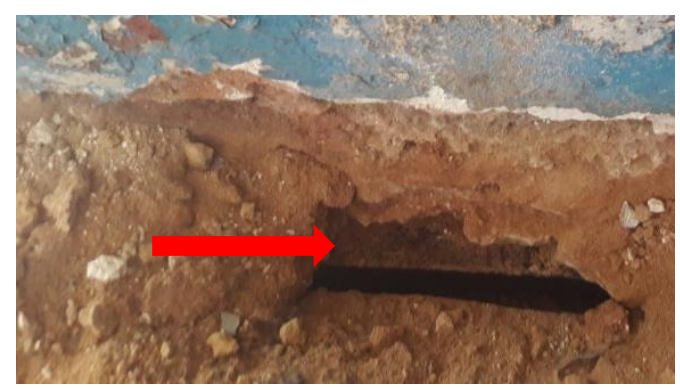

Figure 32. showing how sandstone wall was implemented on I-beams (Abi Rached,E. 2018).

Figure 30. Transversal section for the intermediate slab found in rooms in the surveyed case studies for houses dated to late Ottoman period (Abi Rached,E.

Timber flooring boords

Girders

Machine cut beam

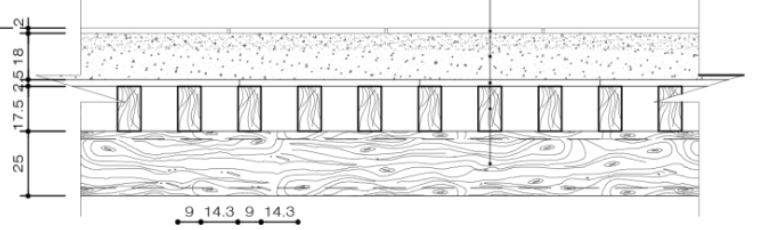
(1) . 
limited use of pre-cast elements comprised of cast iron girders installed on bearing walls with spans ranging from $60 \mathrm{~cm}$ to $80 \mathrm{~cm}$. Between the iron girders, small stone vaults are constructed and plastered from below while concrete is poured from above (Figure 34).

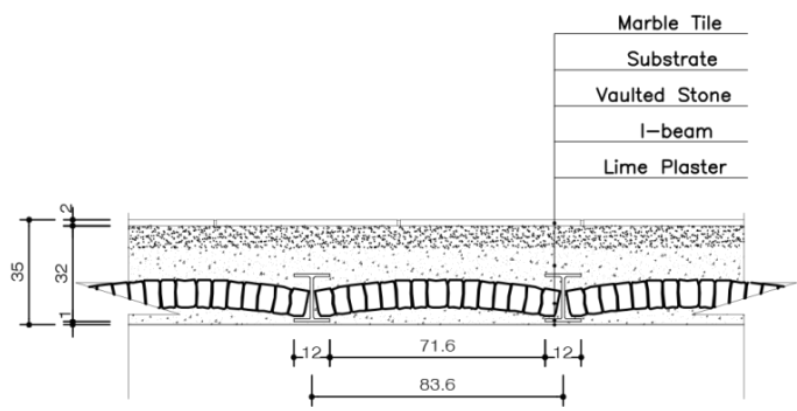

Figure 34. The armed technique using iron rods and stones, where spaces are possible to achieve spans wider. The photo shows in details the existence of Jack arch slab in Bechara el-Khoury mansion. (Hammoud J., 2018)

Type 4: Flat lime concrete roof: It is a non-ventilated flat roof system with the functional layers. It is composed of wooden girders that have a cross section about $17 \times 9 \mathrm{~cm}$. The top of the floor girders was covered with the finely shaped timber boards measuring $(20 \times 2 \mathrm{~cm})$ perpendicular to them. Thin gaps between the boards are sealed with long narrow strips of wood to prevent leakage during the above concreting process. Thick layer of sand and aggregates are placed above the wooden boards satisfying the thermal insulation requirements. Concreting is done in two layers; the bottom layer consists of bigger aggregates, usually pieces of locally available stones. Another layer of lime concrete is poured over it consisting of lime with finer aggregates like broken sea shells, corals and fine sand (Figure 35).
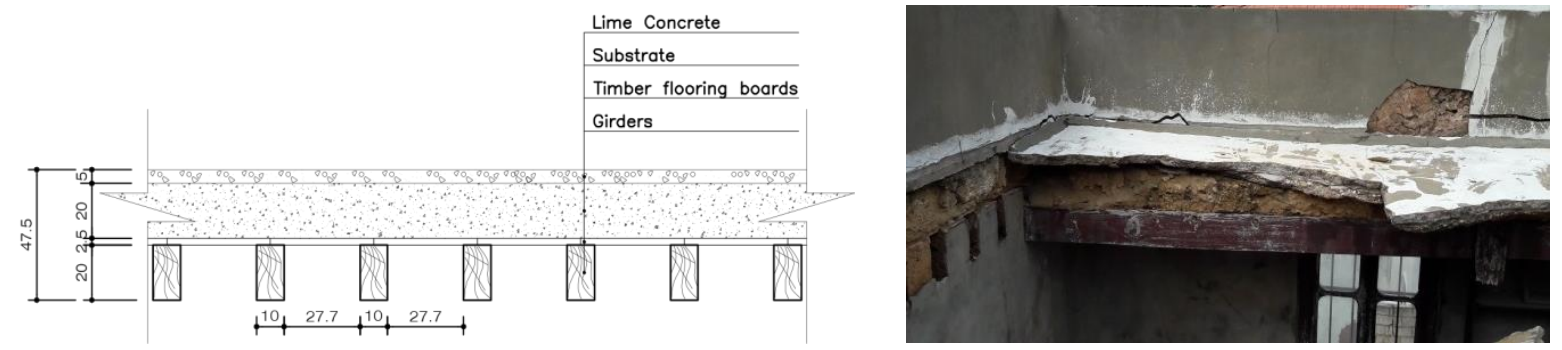

Figure 35. Section of the flat roof in Kaaki house (Hammoud J., 2018)

Type 5: Hybrid timber iron floor: Made of two materials, timber and cast iron, the tension members are made of iron. The compression members are made of timber. Material properties of steel and wood different by combing them in a hybrid structure. I-beams are main beams bearing on a wall for a distance around $60 \mathrm{~cm}$. The secondary beams are the timber joists with wooden sections around $(10 \times 7 \mathrm{~cm})$ spanning in a parallel direction supported and held on the I-beams for a distance of $50 \mathrm{~cm}$. Wooden laths $(2 \times 1.5 \mathrm{~cm})$ are nailed and fixed on the wooden joists which is called Baghdadi construction (lath technique) whereas the outer surfaces were plastered by lime mortar as shown. Steel excels in tension while wood reacts much better to compression slab bearing on I-beam. Timber is brittle in tension, this equates to use the timber components to resist compressive forces, and using steel, or other materials, to resist tensile forces. Therefore, when constructing a hybrid wood/steel, the wood which is called the lumber, should be placed up on top of the I-beam in compression and steel should be placed at the bottom chord to be in tension (Leckie, J. 2008). The top of the lumber was sheathed with the timber flooring boards or plywood perpendicular to them to facilitate the tiling applied at the top of this surface by adding a thick layer of sand and aggregates with lime screed below the marble tiling. Combining steel and wood will increase the seismic performance of the structure. Wood has a high strength to weight ratio therefore wood buildings tend to be lighter than other building types (Figures $36 \& 77$ ). 


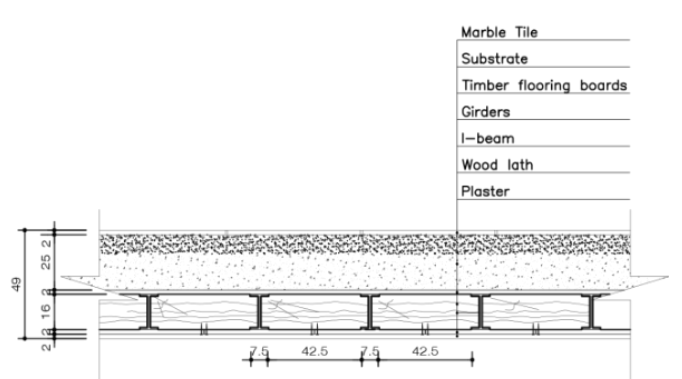

Figure 36. Transversal sections for the hybrid timber iron slab in Al Sabra house (Abi Rached, E. 2019).

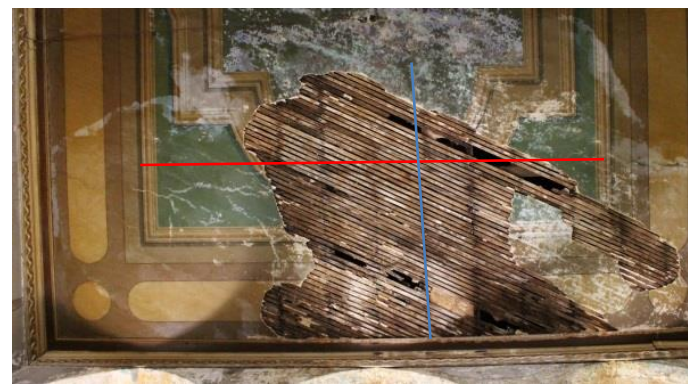

Figure 37. Composition of steel and wood Slab shown in Al Sabra house (Hammoud J., 2018)

Roof Timber Hipped red tile roof (Second half of the nineteenth century): The pitched red tile roof of the Beiruti Boergouisie houses was an assembly of multiple components that work together to create a waterproofing or watershedding system. Its was a major innovation compared to the massive preindustrial flat roof. Although it must be said that it has gone out of favor in recent years, because of its higher cost in materials and labor, but it still reflects an aesthetic preference. This pitch of a roof depends upon the ideas of the builders. In Beiruti houses, $30^{\circ}$ or $35^{\circ}$ is adopted for the pitch, having a rise of one-fourth the span, known also as square pitch. This structure is constructed by using two types of trusses, the King-Post (Figure 38) and the Queen-Post trusses (Figure 39) and some cases a combination between both types like Bchara el-Khoury mansion (Figure 40). This type of roof structure is very restricted in its use. The roof consists of common rafters fixed at the ridge and at the wall plate. When subjected to any type of load or force acting vertically downwards the rafters will move outwards at their feet thus exerting thrust to the walls forcing them outwards and causing possible failure of the wall structure. To stop the ceiling joist from bent, a hanger is fixed to the rafter at the top and the ceiling joist at the bottom. To increase the strength of this structure, a binder is fixed to each ceiling joist and hanger. This binder runs parallel with the main wall and at right angles to the ceiling joist. This type of structure ensures that this type of roof can be used for great spans without the fear of the roof spreading under loads.
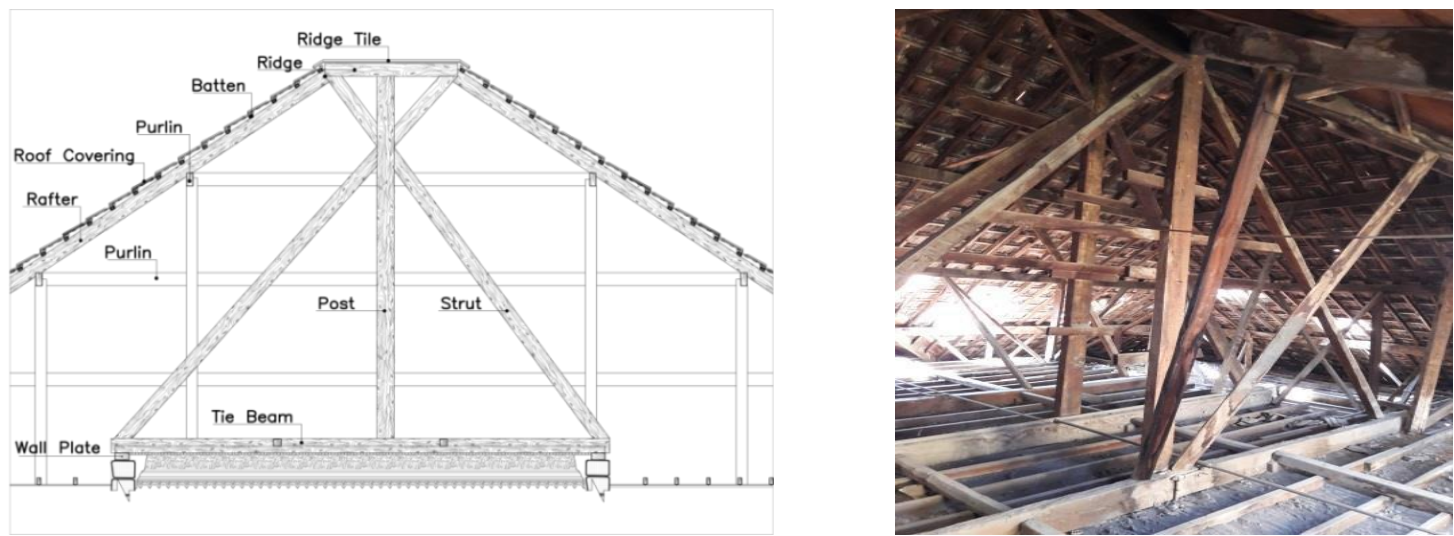

Figure 38. Showing the King post truss in Al-Sabra house (Hammoud J., 2019)
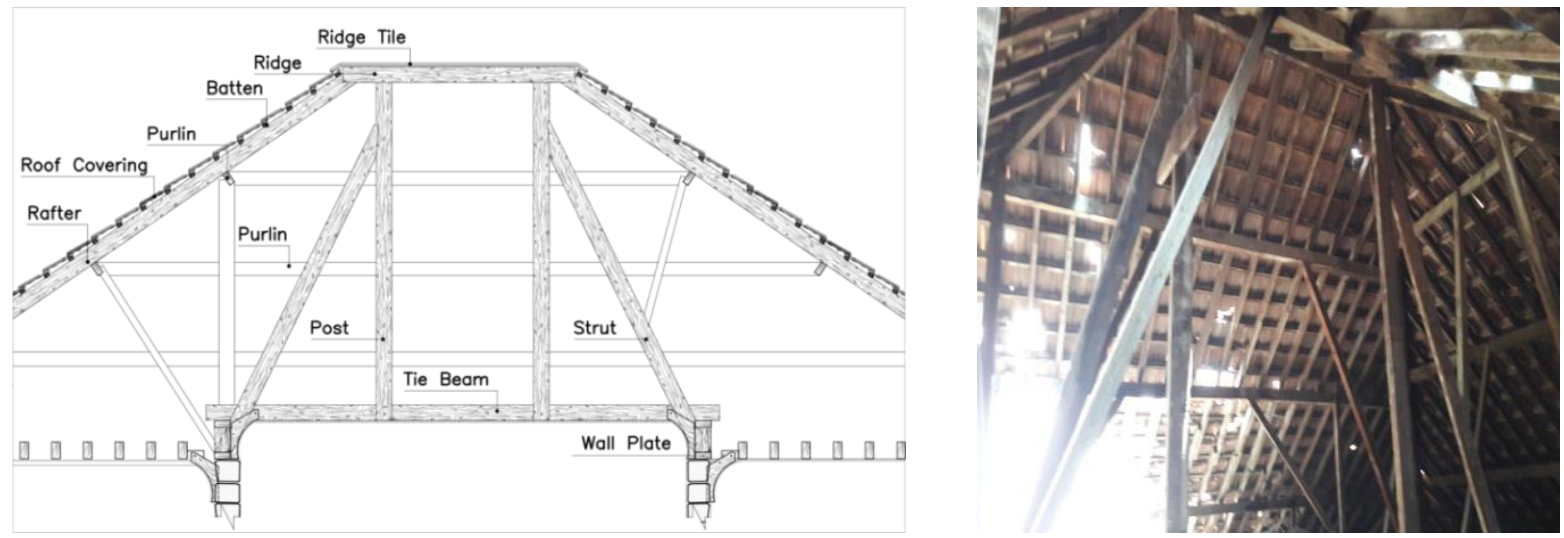

Figure 39. Showing the Queen post truss in kaaki house (Hammoud J., 2018) 

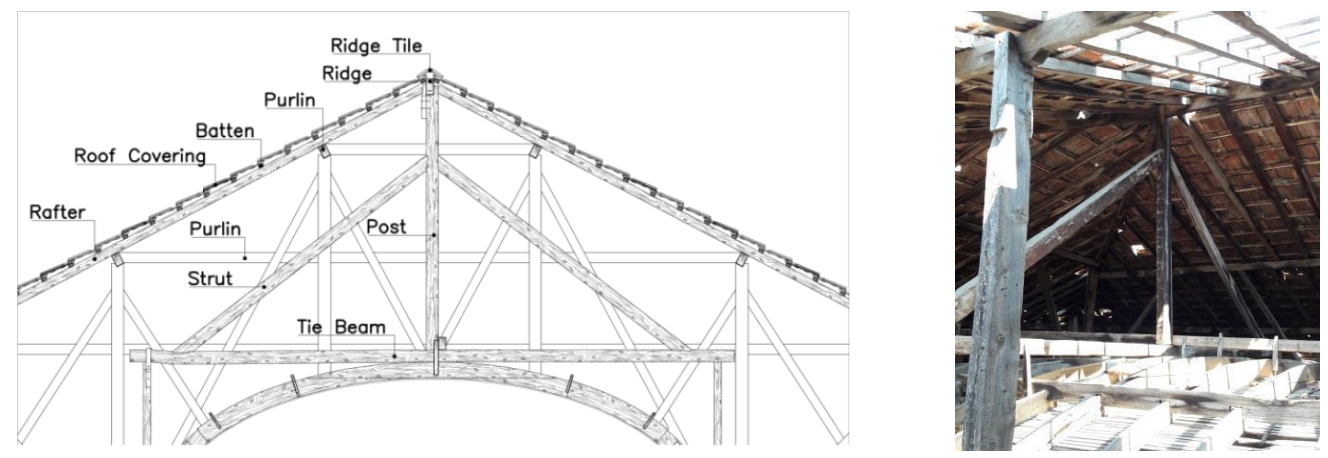

Figure 40. The combination of the King post and the queen truss in Bchara el-khoury mansion.

Before mounting the whole attic reticulated wooden system of this structure, three steps was successfully followed: 1- the installation of wooden top plate over the last sandstone masonry course: The wooden top plate dimensions are around $14 \times 5 \mathrm{~cm}$ that are embedded within the surrounding stones that allow the installation of the ceiling joists onto it.

2- the installation of ceiling joist $(10 \times 5 \mathrm{~cm})$ between walls: This is the typical system traditionally used in Beirut that allows for fixing the ceiling lining (the baghdadi strips). In some cases, the joists are also connected to a hanging beam having vertical proportions $(22 \times 5 \mathrm{~cm})$ dividing the span in two and minimizing the drop of the joists (and therefore of the ceiling).

3- the fixing of "baghdadi strips ( $1 \times 2 \mathrm{~cm})$ ceiling lining between joists.

\subsection{Construction System - Floor Structural Systems (French Mandate Period)}

The welcoming of the concrete material and technology overlapped in Beirut at the early mandate period. In the late Mandate period, first instruction in Spain appears, regulating the use of new materials. Strict regulatory measures directly affected the industry. In the case studies, two type of floor construction exist:

Type 1: Ferro concrete Floor (Mandate Period): According to the symposium done in Spain 2009 "Evolution and Trends in Design, Analysis and Construction of Shell and Spatial Structures in the middle east". It was noticed that the French floor construction in the late Mandate was the Ferro concrete floor. It is a floor of $110 \mathrm{~mm}$ thickness (Figure 41). It consists of closely spaced, continuous layers of mesh or plain rods embedded in hydraulic cement mortar. Ferro concrete is relatively a new material and has good strength and resistance to impact. According to an interview with an old math teacher Abu Abdallah Alzmirli, the materials for the concrete were mixed thoroughly dry on a wood platform, or in a concrete mixing machine, until the colour is uniform, and then be watered gently through a rose until moistened throughout while being again mixed. When ready for use, it should be just in a quivering condition, but not wet enough for the water to be running away. The bars used are round of 10-12 mm diameter forming square mesh of steel bars which has similar characteristics as welded mesh, but is a little more flexible and easy to work with than welded mesh (Figure 42). The cantilevered slabs of $95 \mathrm{~cm}$ a total depth of about $1 / 16$ span, as balconies and end bays of slab.

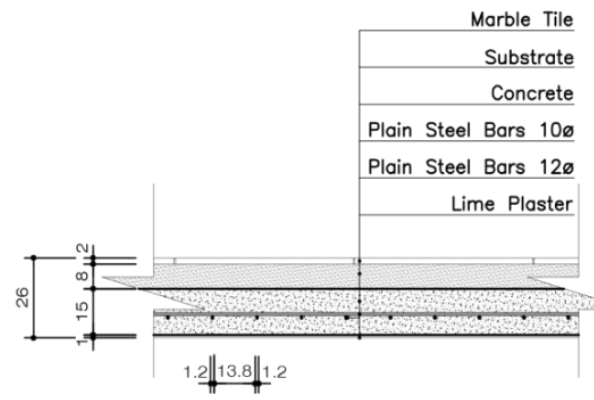

Figure 41. Vertical section for the concrete slab.
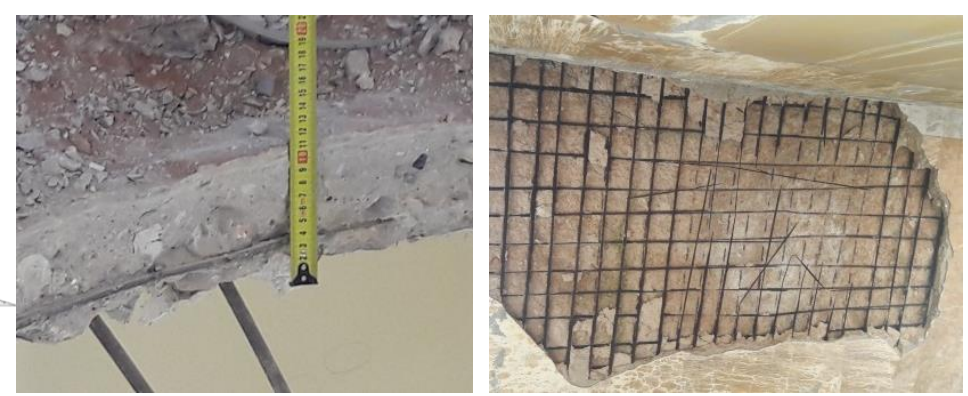

Figure 42. Iron mesh and the concrete slab in Kabbani building 
Type 2: Hollow bricks and concrete floors (Autarkic slabs) (Late Mandate Period) (Beam and block system) The necessary limitations in the usage of metallic elements during the post-war period led to loss in the quantity of steel turns where new solutions increasingly purified to scratch some grams of material in every square meter. In this moment the Autarkic slab spreads the ones that optimize the use of the steel used exclusively where it's irreplaceable to support the tension stress (Paricio, I. 1986). This slab deals with one-way hollow brick and concrete joist systems. To make the concrete joist, reinforcement rods with $12 \mathrm{~mm}$ diameter are placed surrounded with cement mortar constituting a monolithic joist (Figure 43). A juxtaposition of hollow brick pieces joined by cement mortar forming a one-way system. Reinforcement rods and hollow brick pieces are generally placed with concrete; it joins them strongly together and with the framework, until everything forms a constant lightened slab with an easy assembly work. Typically, around $3 \mathrm{~cm}$ clear cover was provided between the round reinforcing bars and the adjacent clay hollow brick and bottom of the exposed concrete surface of the joist. One-way systems were very efficient for spans over $360 \mathrm{~cm}$ and were used very frequently for spans ranged between $385 \mathrm{am}$ and $400 \mathrm{~cm}$ as in Farjallah building.

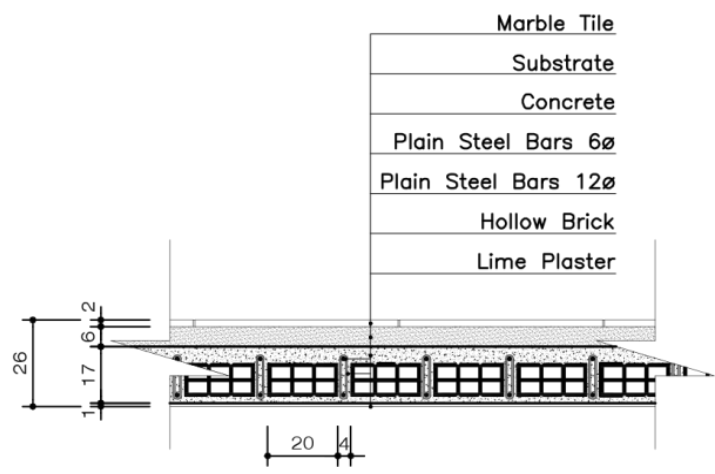

Figure 43. Section in the Autarkic slabs used in Farjallah building (Hammoud J., 2019)

\section{Bending Strength Test for Timber Material}

Timber is a natural organic material that has been used since 1860s in Beirut for the construction of floor slabs. Mechanical properties of timber are of interest for engineers and conservators, for the old timber structure, for the potential reuse of salvaged timbers and for the conservation of cut beams as well. In this paper, the results of testing are presented for aged elements to show the species of the wood.

Mechanical Properties of Timber: Seven samples of wood as shown in figure 44 were received in the Laboratory of Civil Engineering of the University of Aveiro (DECivil - UA) to perform bending strength tests in two specimens and compression strength perpendicular to the grain in the remaining samples. The samples were photographed, weighed and measured prior to testing. For each one a reference was given in order to identify the samples in question. Table 2 shows the dimensions and weights of the samples prior to the grinding and the necessary. The samples A and B were subjected to a bending test in accordance with the European Standard EN 408: 2003 (E) Article 13, and samples C, D, E and F to compression strength perpendicular to grain, EN 408: 2003 (E) Article 18.

Table 2. Dimension of the wood samples(DECivil - UA)

\begin{tabular}{|c|c|c|c|c|c|}
\hline Specimen & $\begin{array}{c}\text { Weight } \\
{[\mathrm{kg}]}\end{array}$ & $\begin{array}{c}\text { Width } \\
{[\mathrm{mm}]}\end{array}$ & $\begin{array}{c}\text { Depth } \\
{[\mathrm{mm}]}\end{array}$ & $\begin{array}{c}\text { Length } \\
{[\mathrm{mm}]}\end{array}$ & $\begin{array}{c}\text { Specific } \\
\text { weight } \\
{\left[\mathrm{kN} / \mathrm{m}^{3}\right]}\end{array}$ \\
\hline A & 0.076 & 14.80 & 22.93 & 424 & 5.18 \\
\hline B & 0.05 & 14.21 & 19.07 & 422 & 4.29 \\
\hline C & 0.589 & 80.00 & 95.00 & 184 & 4.13 \\
\hline D & 0.22 & 77.88 & 72.66 & 76 & 5.01 \\
\hline E & 0.242 & 43.16 & 88.91 & 160 & 3.87 \\
\hline F & 1.632 & 55.58 & 250.00 & 200 & 5.76 \\
\hline
\end{tabular}




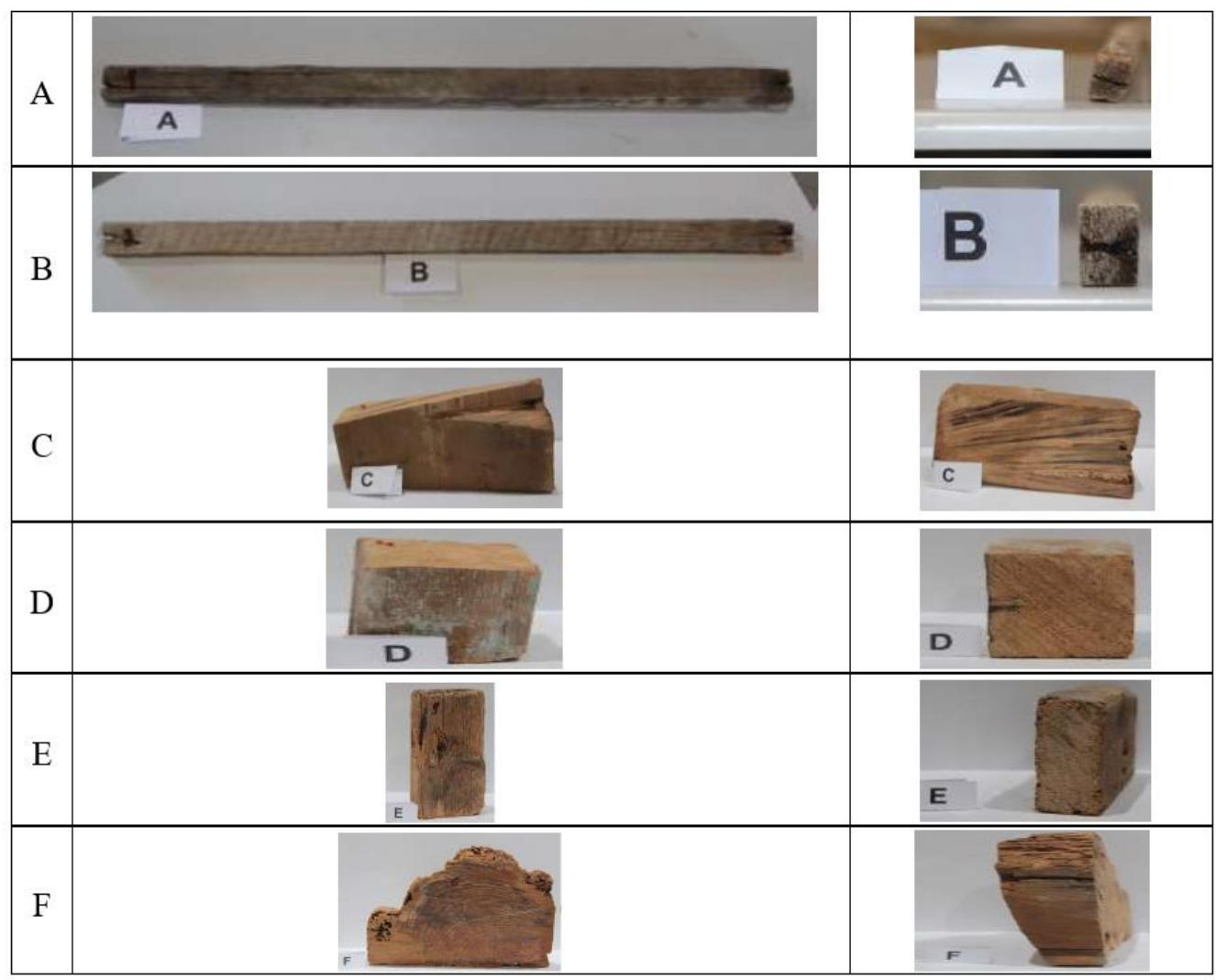

Figure 44. Wood samples deliver to the DECIVIL

\subsection{Determination of Bending Strength}

As mentioned, the samples A and B were not subjected to any type of preparation and were directly subjected to the bending tests. The test scheme for A and B used in figure 45. The distance between supports and the points of application of the load were defined in accordance with Articles 10 and 13 of EN 408: 2003 (E). According to this standard, the parts to be tested shall be symmetrically loaded on a span equal to 18 times the height of the beam and the points of application of the load shall be 5 times the height of the beam. Also, the distance between load points may be change by an amount not greater than 1.5 times the piece depth, having considered for both beams the distance of $110 \mathrm{~mm}$. The beams were simply supported, and lateral restraint was provided, in order to prevent buckling, by a special support made of steel. This support restrains the movement of the pieces out of the plane and allows the piece to deflect without frictional resistance. In order to prevent indentation on the wood pieces four steel plates with $12 \mathrm{~mm}$ in thickness were inserted between the pieces and the loading heads and supports. All the supports and load heads were specifically built, in steel, for the execution of the bending strength test of the two specimens. The results obtained in the tests performed and the symbols were adopted based on the terminology described in the standard EN 408 considered to perform the tests. According to EN 338, wood structures of class C18 have the following mechanical properties.

Table 3. Mechanical properties for pine wood of class $\mathrm{C} 18$

\begin{tabular}{|c|c|c|c|}
\hline $\begin{array}{c}\rho_{k}^{(1)} \\
{\left[\mathrm{kg} / \mathrm{m}^{3}\right]}\end{array}$ & $\begin{array}{c}\mathrm{E}_{90, \mathrm{mean}}{ }^{(2)} \\
{[\mathrm{MPa}]}\end{array}$ & $\begin{array}{l}f_{m, k}^{(1)} \\
\text { [MPa] }\end{array}$ & $\begin{array}{l}f_{c .90 . k}(1) \\
\text { [MPa] }\end{array}$ \\
\hline 320 & 300 & 18 & 4.8 \\
\hline
\end{tabular}




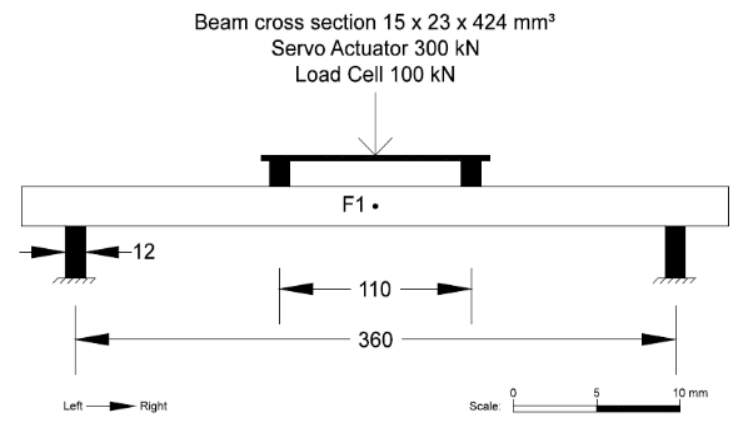

Figure 45. Test setup for the determination of bending strength

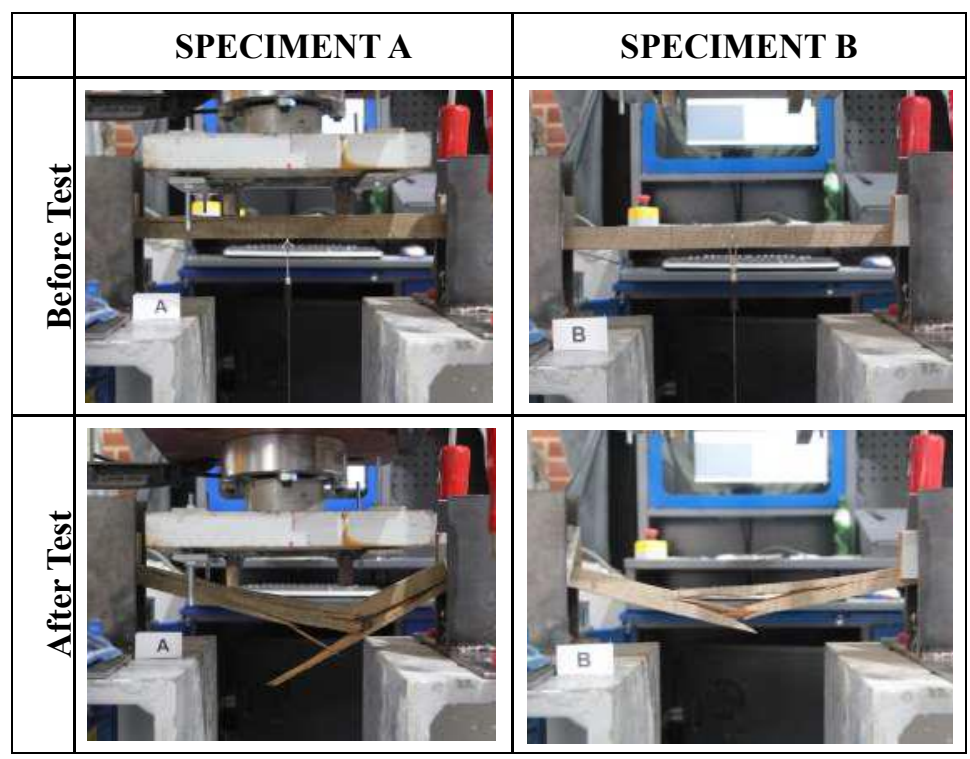

Figure 46. Specimens A and B before and after the tests
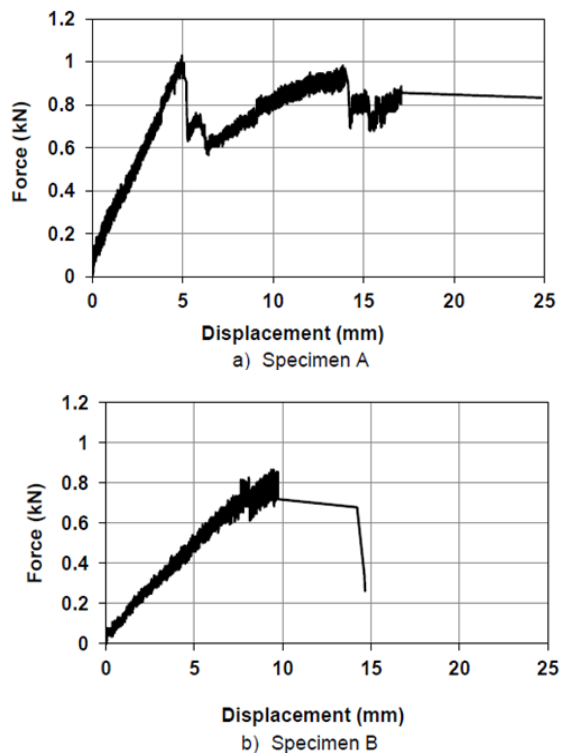

Figure 47. Load -deformation graphs of wood specimens subject to bending strength: a) specimen A; b) specimen $B$ 
For bending strength, specimen A had a rupture with some ductility, that is, the fibres were breaking throughout the test, with some force decreases but remaining more or less constant until the final rupture occurs, while specimen B showed a fragile rupture. In figure 46, it is possible to visualize the damages that the beams presented after the tests. The diagrams Force vs. Displacement for the specimen A and B are presented in Figure 47 and in table 3 the results of the bending strength test. The Force versus Displacement diagrams presented in Figure 47 exhibit a linear behaviour until the maximum force occurs. This behaviour is more evident in specimen A. After the maximum force the fibres of the wood break, presenting a decrease in force and an increase of displacement. For both specimens the final fragile rupture caused the displacement transducers to loosen from the face in which they were attached, so that in the final phase of the curve on diagram Force vs. Displacement, Figure 47 a) and b) the curve becomes a straight line due to the detachment of the sensor from the face of the beam.

Table 4. Bending strength results for wood sample A and B (DECivil - UA)

\begin{tabular}{|c|c|c|c|c|}
\hline Specimen & $\begin{array}{c}F_{\max } \\
{[\mathrm{kN}]}\end{array}$ & $\begin{array}{c}f_{\mathrm{m}} \\
{[\mathrm{MPa}]}\end{array}$ & $\begin{array}{c}\mathrm{E}_{\mathrm{m} . \mathrm{s}} \\
{[\mathrm{MPa}]}\end{array}$ & $\begin{array}{c}\text { Displacement } \\
\text { to } F_{\max }[\mathrm{mm}]\end{array}$ \\
\hline $\mathrm{A}$ & 1.03 & 49.56 & 9835 & 4.96 \\
\hline B & 0.87 & 62.90 & 4834 & 9.37 \\
\hline Mean & 0.95 & 56.23 & 7334 & 7.16 \\
\hline Standard deviation & 0.11 & 9.43 & 3535 & 3.12 \\
\hline CoV (\%) & $12 \%$ & $17 \%$ & $48 \%$ & $44 \%$ \\
\hline
\end{tabular}

Table 4 shows the results obtained in the bending strength tests for specimens A and B, in accordance with standard EN 408 for bending strength and for the global modulus of elasticity in bending. Although both beams appear to be of the same type of wood, a medium dispersion $(\mathrm{CoV})$ where obtained for the value of the maximum load force and the respective bending strength while the global modulus of elasticity in bending has a high dispersion. These values are clearly affected by the number of sample values and a higher number of samples are preferred in order to more accurately measure the desired values. The mean value of bending strength obtained suggests that the pieces of wood belong to the deciduous species of class D50, in accordance with EN 338.

\subsection{Determination of Compression Strength Perpendicular to Grain}

Prior to the tests, the C, D, E and F samples were cut and rectified in order to present the relationship between base, length and height defined in the standard EN 408: 2003 (E), for the determination of compression strength perpendicular to the grain. In table 4 are presented the average dimensions of test pieces after the rectification. The test setup of the compression perpendicular to the grain is shown in figure 48. Given the small dimensions of the test specimens to be tested and in order to measure their deformation, two wire transducers (F1 and F2) were used to measure the displacement of the top plate and the support base plate of the test piece and consequently the deformation of the test specimen.

Table 5. Dimensions used in the determination of compression strength perpendicular to the grain(DECivil - UA)

\begin{tabular}{|c|c|c|c|c|c|}
\hline & & ${ }^{1}$ & L & & \\
\hline Sample & $\begin{array}{c}\text { Test } \\
\text { specimen }\end{array}$ & $\begin{array}{l}\text { Width } \\
\text { (b) } \\
\text { [mm] }\end{array}$ & $\begin{array}{l}\text { Depth } \\
\text { (L) } \\
\text { [mm] }\end{array}$ & $\begin{array}{c}\text { Height } \\
\text { (h) } \\
\text { [mm] }\end{array}$ & $\begin{array}{c}\text { Cross Section } \\
\text { Area (b } x \text { L) } \\
{\left[\mathrm{mm}^{2}\right]}\end{array}$ \\
\hline \multirow{4}{*}{ C } & C1 & 42,84 & 68,90 & 80,24 & 2951,12 \\
\hline & C2 & 51,52 & 44,75 & 83,12 & 2305,46 \\
\hline & C3 & 46,15 & 66,66 & 81,58 & 3076,03 \\
\hline & C4 & 44,49 & 59,46 & 82,13 & 2645,35 \\
\hline \multicolumn{2}{|c|}{ D } & 57,16 & 77,93 & 77,73 & 4454,54 \\
\hline \multirow{2}{*}{ E } & E1 & 68,33 & 42,78 & 89,78 & 2923,07 \\
\hline & E2 & 68,95 & 43,94 & 89,06 & 3029,60 \\
\hline \multirow{2}{*}{$\mathbf{F}$} & F1 & 60,61 & 66,02 & 56,85 & 4001,17 \\
\hline & F2 & 60,78 & 64,51 & 59,10 & 3921,13 \\
\hline
\end{tabular}




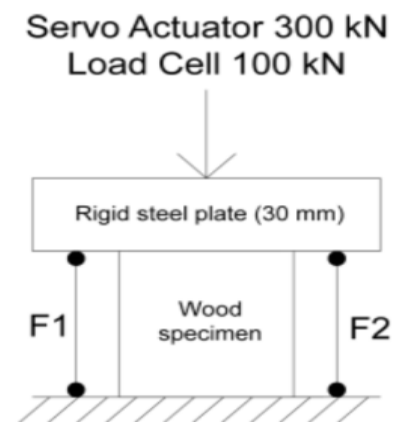

Figure 48. Test setup for compression strength perpendicular to grain test(DECivil - UA)

The determination of compression strength perpendicular to grain were carried out on the wood samples C, D, E and F. Sample $\mathrm{C}$ were cut and rectified in to 4 specimens of approximately the same size, although visible marks left by a metallic element have diminished the cross section of specimen C1. Test sample D was only rectified in order to maintain the 6 faces of the cube orthogonal. Sample E was cut in half which allowed obtaining two specimens with the standard dimensions defined in the standard EN 408. Sample F had two oblique faces between them and the orientations of the fibres perpendicular to the oblique faces have limited a greater number of test pieces (Figure 49). In most tests, it was verified the crushing of the wood and the separation of the fibres during the test with punctual ruptures that translate into points of inflection in the curves of the load-deformation diagrams. It was also verified that the wood specimens with more moisture, tend to form a bulb with little fibre separation, causing the increase of force after the rupture of the specimen have already occurs and after the wood specimen shown heavy compression displacement. After the relief of the compression load, the recovery of some displacement is verified, due to the elasticity of the wood and the repositioning of the fibres after the tension released.
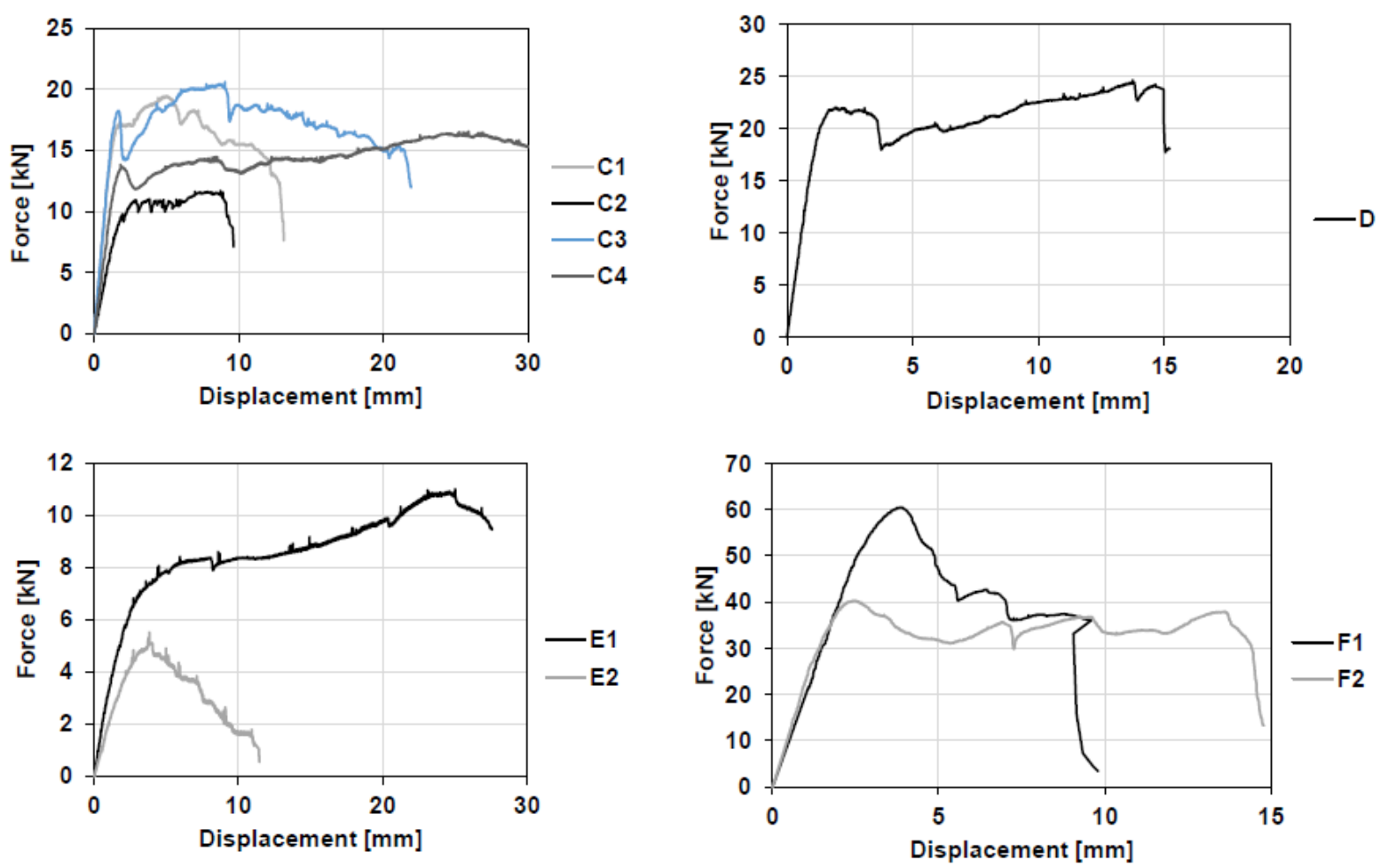

Figure 49. Load-Deformation graphs of the compression perpendicular to the grain tests of samples C, D, E and 


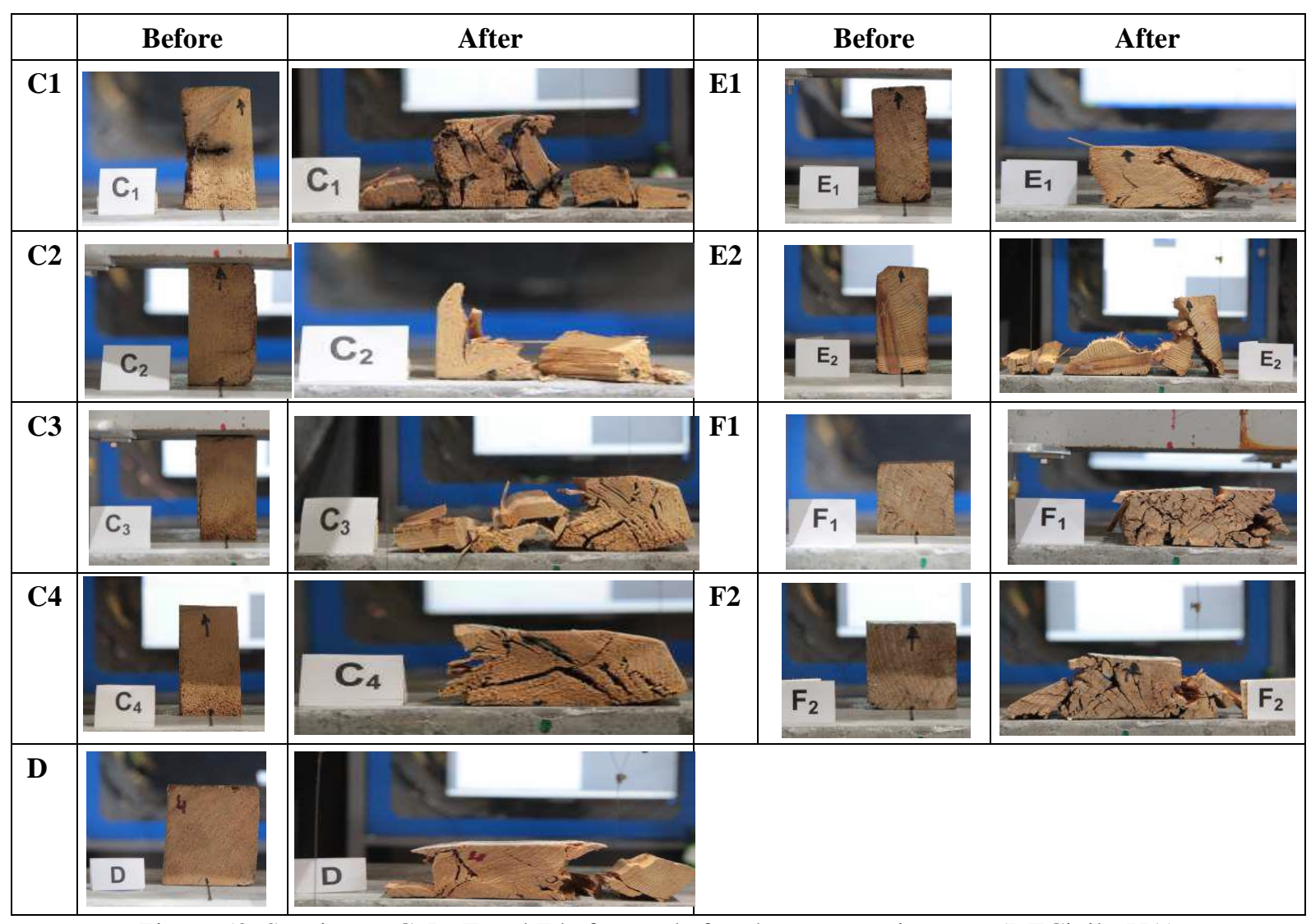

Figure 50. Specimens C, D, E and F before and after the compression tests (DECivil - UA)

It was decided to leave the complete curve of the load-displacement diagrams since the rupture in compression perpendicular to the grain considered in EN 408 occurs immediately after the elastic phase. However, the test specimens, for the most part, still have load and deformation capacity after this point. The results of sample C showing a mean compression strength perpendicular to grain point out that the strength class, according to EN338, of sample C is between a C18 and a C22. According to EN338 the strength class of sample D is a C18. Sample E had shown a high dispersion in the obtained values of load, tension and displacement, This may be related to the fact that the E2 specimen has marks of, at some point of is lifespan, having a metallic element inside, that cause a reduction of is cross section, and this specimen also had damage caused by the presence of Xylophages insects, which may explain the high dispersion of result values obtained for this sample. The mean compression strength perpendicular to the grain is the lowest of the 4 samples with a value of $1.96 \mathrm{MPa}$, with no classification in the EN338. Sample F shows an average dispersion values in the results obtained, due to the good quality of the wood. Considering the compressive strength this is a wood from a deciduous species with a class between D60 and D70.For all the compression strength perpendicular to grain tests, the obtained values for had shown medium to high dispersion. This is due to the wood elastically properties and that section to section these properties could change due to external factors like the growth of the mother tree, contamination and damage throughout the lifespan of the samples.

\section{Conclusion}

The lack of knowledge about floor construction systems dated to the late Ottoman and French mandate period, and the difficulty of characterizing their structural performance and their state of conservation leads to find the significant background knowledge for the evolution of floor systems encompassing multidisciplinary approaches for future interventions. In this paper, the importance and evolution of floor construction systems were presented. The study has then been concentrated in the description of the building materials and construction of floor structural system and for the bending strength tests for timber used in floors. It was demonstrated that we can learn from past and prepare for a conservation approach and more effective activities. Particularly, the actual techniques even if sophisticated, are not able to investigate completely the real situation. Therefore, they will not survive indefinitely without periodic care and attention and there is the risk to lose important information. The paper found that traditional experience of floor slab construction is the best source of knowledge. The phenomenon of the 
continuous evolution of floor construction techniques which has increased acceleration by the technical developments over the centuries includes the knowledge and experiences inherited from early humans and pass it to the future. This might be described as "the reflection of traditional construction techniques and structures on modern buildings". Therefore, the flooring construction systems have been explained by its characterization and the laboratory tests. Floor slabs demonstrated to be an effective, high performance and reason to be protected and preserved by using proper measures and compatible interventions in terms of materials, techniques and strategies that can guarantee the future use of the Beiruti bourgeoisie houses and mandate buildings. Future research will be concentrated in developing an adaptive reuse stages and its relation with its surrounding constructions, in order to achieve less intrusive actions, maintaining the cultural value of the constructions.

\section{References}

Adams, H. (1906). Adams' Building Construction. (J. W. Campbell, Ed.) New York, USA: Routledge. ISBN 13:978-1-873394-93-9.

CEN, EN 338. (2008). Structural timber - Strength classes. 1995, Comité Européen de Normalisation.Leckie, J.

CEN, EN 408. (2003). Timber structures - Structural timber and glue laminated timber - Determination of some physical and mechanical properties. Comité Européen de Normalisation.

CEN, EN ISO 15630-1. (2010). Steel for the reinforcement and prestressing of concrete - Test methods - Part 1: Reinforcing bars, wire rod and wire.

CEN, EN ISO 6892-1. (2009). Metallic materials - Tensile testing - Part 1: Method of test at ambient temperature.

De Perthuis (1853). Voyages en Orient, Journal de la Comtesse de Perthuis, 1853-1855 \& 1860-1862. Beirut: Dar An-Nahar, 2007. ISBN 10: 9953741328.

Fischfisch, A. (2011). Formes urbaines et architecturales de Beyrouth (Depuis le XIXe Siècle jusqu'à nos jours). Beirut, Lebanon: ALBA. ISBN-13: 9789953452364.

Leckie, J. (2008). Steel and Other Material Part Two: Steel and Wood. Advantage Steel, 8-10. https://doi.org/10.14288/1.0166422

Paricio, I. (1986). La construcción de la arquitectura. Los elementos. Barcelona: Institut de Tecnología de la Construcció.

Ragette, F. (1998). Architecture in Lebanon. New York. ISBN-13: 9780882060414.

Ragette, F. (2006). Traditional Domestic Architecture of the Arab Region. AUS. ISBN-13:978-3-932565-30-4.

Saliba, R. (1998). Beirut 1920-1940: Domestic Architecture Between Tradition and Modernity. Beirut, Lebanon: The Order of Engineers and Architects. ISBN-13: 978-9990000054.

Saliba, R. (2004). The Genenis of Modern Architecture in Beirut, 1840-1940. In J. Abed (Ed.), Architecture Reintroduced: New Projects in Societies in Change (pp. 23-39). Beirut, Lebanon: THE AGA KHAN AWARD FOR ARCHITECTURE.

Salibi, K. (1988). A House of Many Mansions: The History of Lebanon Reconsidered (1st ed.). California, USA: University of California Press. ISBN13: 9780520071964.

Sehnaoui, N. (1981). L'occidentalisation de la vie quotidienne à Beyrouth: 1860 - 1914. M.A. Thesis: (University of Paris).

\section{Copyrights}

Copyright for this article is retained by the author(s), with first publication rights granted to the journal.

This is an open-access article distributed under the terms and conditions of the Creative Commons Attribution license (http://creativecommons.org/licenses/by/4.0/). 